\title{
ENJOY THE SILENCE: \\ Pseudolaw AT The SuPREMe Court of CANADA
}

\author{
DONALD J. NETOLITZKY ${ }^{*}$ AND RICHARD WARMAN**
}

\begin{abstract}
Pseudolaw is a collection of legal-sounding but false rules that purport to be law, employed by groups including the Detaxer and Freemen-on-the-Land movements. While pseudolaw is universally rejected by Canadian courts, no Supreme Court of Canada decision addresses these concepts. This study reviews 51 unsuccessful Supreme Court leave applications that potentially involve pseudolaw to determine what pseudolaw issues were raised, whether those issues were comprehensible, and therefore if by its silence the Supreme Court has implicitly rejected these concepts.
\end{abstract}

Some pseudolaw-related leave applications were not comprehensible to a legally trained reader; however, the remainder clearly imply that the Supreme Court of Canada has been exposed to the cornerstone concepts of modern pseudolaw, including "Strawman" Theory, and has rejected these ideas as not having national significance.

\section{TABLE OF CONTENTS}

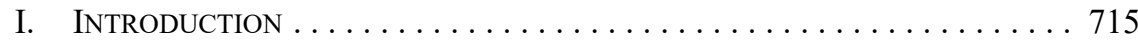

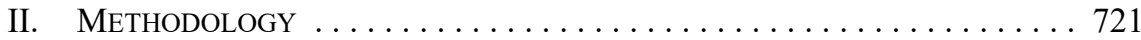

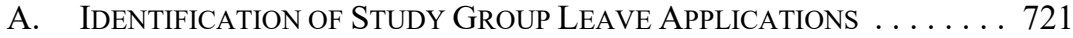

B. InVESTigation of StUdy GROUP LEAVE APPLICATIONS $\ldots \ldots 722$

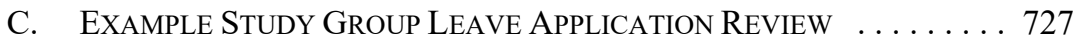

III. RESULTS . . . . . . . . . . . . . . . . . . . . . . . . . . . 729

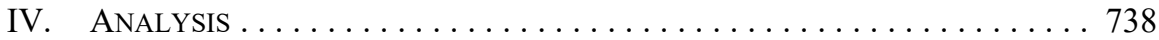

A. IMPlicitLy ReJeCted PSEUdolaw Motifs ANd CONCEPTS . . . . 738

B. CANAdian APPELlate OPCA Litigation $\ldots \ldots \ldots \ldots \ldots \ldots 742$

C. SELF-Represented Litigants AT THE

SUPREME COURT OF CANADA ................... 761

D. Should the Supreme Court of Canada Grant Leave? . . . . . 763

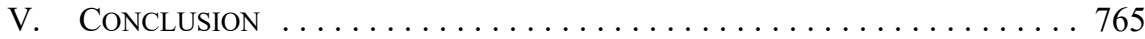

\section{INTRODUCTION}

Each week the Supreme Court of Canada issues a Bulletin that identifies significant litigation developments in that institution. Weekly Bulletins include a list of appeals that were filed but then denied leave. Most attempts to access the high court of Canada end this

PhD Microbiology, University of Alberta, 1995; LLB, University of Alberta, 2005; Complex Litigant Management Counsel for the Alberta Court of Queen's Bench. The views expressed in this article are those of the author, and not those of any other member of the Court of Queen's Bench, or the Court itself.

** LLB, University of Windsor, 1998; LLM, McGill University, 2004. 
way. Those applications will never be heard. ${ }^{1}$ Given most applicants are represented by a lawyer, it is a rare occasion when leave is granted to a self-represented litigant (SRL). ${ }^{2}$

The Supreme Court Act criteria for leave are broad. The Supreme Court may take jurisdiction where a question is of "public importance," or where "the importance of any issue of law or any issues of mixed law and fact involved" requires it, or where otherwise warranted. ${ }^{3}$ No reasons are provided when a leave application is rejected. ${ }^{4}$

Many rejected leave applications are cyphers. The Supreme Court website only publishes leave application court filings if leave is granted. Since 2005, the Office of the Registrar (Law Branch) has prepared brief case summaries for the Supreme Court Bulletins. Otherwise, the facts, issues, and law in dispute may only be inferred from lower court judgments, provided those decisions have been reported.

But, sometimes, among this mortuary list of stillborn appeals, a style of cause stands out, and hints that something unusual is afoot. For instance, Supreme Court docket records indicate that on 2 May 2014 a leave application was filed in an action between: "Elio, A Flesh and Blood Human Being, of the Family Dalle Rive, Authorized Representative of 'Elio Dalle Rive' v. Her Majesty the Queen, et al."5

However, the Supreme Court clerks did not accurately reproduce this action's style of cause. The paper leave application instead reads: "Elio, A FLESH AND BLOOD HUMAN BEING, OF THE FAMILY Dalle Rive, AUTHORIZED REPRESENTATIVE OF 'ELIO DALLE RIVE' and HER MAJESTY THE QUEEN, WILLIAM F. PENTNEY DEPUTY ATTORNEY GENERAL OF CANADA." 6

To a reader only familiar with "mainstream" Canadian law, the choice of capitalized and mixed case words might seem arbitrary or accidental. It is not. This is a coded pattern of language derived from an unorthodox set of rules where the letter case of these words has meaning.

"02 Applications for Leave Submitted" (28 February 2018), online: <scc-csc.ca/case-dossier/stat/cat2eng.asp $x>$. Some criminal appeals heard by the Supreme Court are heard as appeals by right, per Criminal Code, RSC 1985, c C-46, ss 693(1)(a), 691(2)(a)-(b), 692(1)(a)-(b), 692(2), 692(3)(a), 693(1)(a) [CC]; Supreme Court Act, RSC 1985, c S-26, ss 37-38 [SCA]. See also Eugene Meehan et al, Supreme Court of Canada Manual: Practice and Advocacy (Toronto: Thomson Reuters, 2019) at Part 4:20.

In 2017, one SRL application was granted leave ( $\mathrm{N}=129)$ : Mazraani v Industrial Alliance Insurance and Financial Services, Inc, 2017 FCA 80, leave to appeal to SCC granted, 37642 (2 November 2017).

SCA, supra note $1, \mathrm{~s} 40(1)$.

$R v$ Hinse, [1995] 4 SCR 597 at para 8.

Supreme Court of Canada, "SCC Case Information" (9 February 2018), online: <scc-csc.ca/casedossier/info/result-resultat-eng.asp $x$ ?cas $=\& p a r=0000 \& n=\& p r o v=\&$ fed $=\&$ jur $=\& p a g e=32>$.

Dalle Rive v R (2 May 2014), Ottawa SCC 35874 (Notice of Appeal) [Dalle Rive 35874]. All paper leave applications in this article are identified by the last name of the first appellant and the Supreme Court of Canada docket number. Copies of the applications are on file with the authors. 
The applicant, Elio OF THE FAMILY Dalle Rive, is indicating he is the flesh-and-blood physical human aspect of a duality, where the other half is "ELIO DALLE RIVE," a noncorporeal "legal person" doppelganger, often called the "Strawman."7 According to "Strawman" theory, a name in all capital letters is the textual cue that distinguishes the man "Elio OF THE FAMILY Dalle Rive" from his legal shadow self "ELIO DALLE RIVE."

Here, Elio in the flesh is purportedly representing ELIO the "Strawman." Beyond that, the nature of the appeal is uncertain. An interested investigator would only be able to reconstruct an ill-defined sketch of what brought Elio into a dispute with Canada and the Deputy Attorney General.

The brief Tax Court of Canada reasons simply dismiss Elio's appeal of his income tax reassessment as an abuse of process. ${ }^{8}$ Elio at that proceeding demanded proof that the Income Tax Act ${ }^{9}$ applies to a "flesh and blood" human, and: "Legal recourse against all parties continuing with unlawfully attacking and forcing involuntary servitude, involuntary contracts and the unlawful enforcement of any other judicial jurisdiction other than Inherent Jurisdiction upon Elio, child of God, an individual, of the family Dalle Rive."10

The docket record insinuates these name structures were also important in the subsequent Federal Court of Appeal proceeding, since there are affidavits filed by "ELIO DALLE RIVE," "Elio, of the family Dalle Rive," and a court instruction that the appellant's name must be amended to "Elio Dalle Rive," or else the action would be dismissed. ${ }^{11}$

This is a useful point to pause and acknowledge that some aspects of the distinction being made by Elio and ELIO are not entirely unanchored from Commonwealth common law history, and the principles and concepts inherited by Canadian courts from their English predecessors. Historically, English common law has, in fact, identified human beings who are not "persons" before the law. ${ }^{12}$ The law of England recognized "villeins," typically agricultural workers, who were the property of whomever owned the land occupied by the villein. At one point, it was lawful in the British Empire, including what has become Canada, for human beings to be bought, held, and sold as chattel property, until that practice was abolished in $1833 .^{13}$

Reviewed in Donald J Netolitzky, "Organized Pseudolegal Commercial Arguments as Magic and Ceremony" (2018) 55:4 Alta L Rev 1045 at 1069-78 [Netolitzky, "Magic"]; Donald Netolitzky, "A Rebellion of Furious Paper: Pseudolaw as a Revolutionary Legal System” (Paper delivered at the CEFIR Symposium: Sovereign Citizens in Canada at Concordia University, Montreal, 3 May 2018) at 15-16 [unpublished], online: <researchgate.net/publication/325053364_A Rebellion_of Furious Paper Pseudolaw_as_a_Revolutionary_Legal_System $>$ [Netolitzky, "Rebeellion”]; Caesar Kalinowski IV, “' $\overline{\mathrm{A}}$ Legal Response to the Sovereign Citizen Movement" (2019) 80:2 Mont L Rev 153.

Dalle Rive $v$ R, 2013 TCC 243 [Dalle Rive].

RSC 1985, c 1 (5th Supp) [ITA].

Dalle Rive, supra note 8 at para 2.

Dalle Rive v R (3 March 2013), Ottawa A-287-13 (FCA) (docket records dated 9 October 2013, 27 January 2014, 7 February 2014: Federal Court, "Court Files," online: <fct-cf.gc.ca/en/court-files-anddecisions/court-files\#tab01>).

12 Reviewed in Pomerleau v Canada (Revenue Agency), 2017 ABQB 123 at paras 89-95 [Pomerleau]. The Slavery Abolition Act 1833 (UK), 3 \& 4 Will 4, c-73. 
The English common law has traditionally identified children as non-person property of their father, ${ }^{14}$ though the Supreme Court has explicitly relegated that approach to children's rights to the ash heap of history. ${ }^{15}$ Similarly, women's status as "persons" was only affirmed in the famous 1929 Privy Council "Persons Case." "16

Thus, English and Canadian law has, in the past, recognized human beings who are not "legal persons." Now, in the modern age, we are all both human beings and "legal persons." But is there a way to somehow untangle that linkage and, if so, what would be the result?

If Elio and ELIO are correct and he is divided or divisible into two distinct parts, one physical, one non-corporeal and legal, and that each can appear in court and engage in litigation independent of the other, then that would represent a fundamental revolution to Canada's legal order. There is much Canadian jurisprudence that rejects this possibility, ${ }^{17}$ but none is from the Supreme Court itself.

So, if Elio and ELIO had argued their dual character in the 2 May 2014 leave application as the central point of that appeal, then one may infer that the failure of the Supreme Court to grant leave indicates the Supreme Court has rejected that one can disconnect the human being from its legal character and status. Elio and ELIO's application would otherwise seem to meet the public importance leave criteria.

To the average lawyer, judge, or, for that matter, Canadian citizen, all this likely seems nothing more than an academic exercise, a thought experiment. However, there is a small but often highly committed collection of individuals in Canada ${ }^{18}$ and other countries ${ }^{19}$ who believe in a different, dissident version of law. They are commonly known as Sovereign Citizens, Freemen-on-the-Land, Detaxers, and Moors. The "Strawman" duality is among their keystone beliefs. ${ }^{20}$

William Blackstone, Commentaries on the Laws of England, in Four Books, vol 1, 12th ed (London: A Strahan and W Woodfall, 1793) at 452-53.

$15 \quad B(R) v$ Children's Aid Society of Metropolitan Toronto, [1995] 1 SCR 315 at para 85; Chamberlain v Surrey School District No 36, 2002 SCC 86 at para 106; Canadian Foundation for Children, Youth and the Law $v$ Canada $(A G), 2004$ SCC 4 at para 225.

16 Re Section 24 of the BNA Act, [1930] 1 DLR 98 at 108 (UK PC).

17 See Meads v Meads, 2012 ABQB 571 at paras 417-46 [Meads]; Pomerleau, supra note 12 at paras 67-96; Fiander $v$ Mills, 2015 NLCA 31 at paras 20-21, 40 [Fiander]; Potvin (Re), 2018 ABQB 652 at paras $110-20$ [Potvin].

18 Donald J Netolitzky, "The History of the Organized Pseudolegal Commercial Argument Phenomenon in Canada" (2016) 53:3 Alta L Rev 609 at 635-36 [Netolitzky, "History"]; Barbara Perry, David C Hofmann \& Ryan Scrivens, "Broadening our Understanding of Anti-Authority Movements in Canada" (2017) Canadian Network for Research on Terrorism, Security and Society Working Paper No 17-02. Stephen A Kent, "Freemen, Sovereign Citizens, and the Challenge to Public Order in British Heritage Countries" (2015) 6 Intl J Cultic Studies 1; Donald J Netolitzky, "A Pathogen Astride the Minds of Men: The Epidemiological History of Pseudolaw" (Paper delivered at the CEFIR Symposium: Sovereign Citizens in Canada, 3 May 2018) [unpublished], online: <researchgate.net/publication/325053635 A Pathogen_Astride the Minds_of Men_The Epidemiological_History_of Pseudolaw $>$ [Netolitzky, "Pathogen"]; Terri A March-Safbom, Weapons of Mass Distraction: Strategies for Countering the Paper Terrorism of Sovereign Citizens (MA Thesis, Naval Postgraduate School, 2018) at 15-24 [unpublished], online: Homeland Security Digital Library <hsdl.org/?view\&did=811407>; Colin McRoberts, "Tinfoil Hats and Powdered Wigs: Thoughts on Pseudolaw" (2019) 58:3 Washburn LJ 637.

20 Netolitzky, "Magic," supra note 7 at 1067-78; Netolitzky, "History," supra note 18 at 633-35; Netolitzky, "Rebellion," supra note 7; Kalinowski, supra note 7 at 158-61, 164-67. 
We, "the mainstream," say their alternative version of law is wrong. We call it "pseudolaw" - spurious concepts that sound like law, and which may use legal terminology, but that are otherwise unrelated to 'true' or 'conventional' law. ${ }^{21}$ The lengthy and often cited 2012 Meads decision of Associate Chief Justice Rooke of the Alberta Court of Queen's Bench provided a systematic rebuttal to pseudolaw, and grouped these concepts under a novel identifying label: "Organized Pseudolegal Commercial Arguments" (OPCA). ${ }^{22}$

However, to that minority who resist or reject conventional law, Meads was not an answer. Instead, litigants who employ OPCA concepts continue to appear in Canadian courts, as they attempt to enforce what they perceive (falsely) as their legal rights. Their litigation is invariably unsuccessful; consumes state, institutional, and court resources; and often causes grave harm to the OPCA litigants themselves. ${ }^{23}$ Worse, pseudolaw is sometimes (falsely) identified as a lawful basis and justification to attack "outlaws" who deny the truth and operation of pseudolaw. ${ }^{24} \mathrm{~A}$ small fraction of the OPCA believer population has resorted to violence. ${ }^{25}$

Members of pseudolaw communities are often rebels or revolutionaries, but of a peculiar kind. The primary mechanism to achieve their desired end is not force, but a competition of laws conducted within the court apparatus. ${ }^{26}$

That observation means these individuals generally do accept the validity and operation of courts as institutions that mediate social behaviour and interactions. Obviously, saying that is more than a little incongruous when one considers the wealth of OPCA strategies that are designed to negate or deny court authority, ${ }^{27}$ and how OPCA litigants often appear in court, but only to contest that a court has jurisdiction. While this is true, that fact does not mean, however, that OPCA litigants are saying: "There are no courts; there is no law." Rather, their belief and conduct reflects a perspective where courts have a different or more restricted role, rather than that judicial institutions are simply illegitimate. ${ }^{28}$

Donald J Netolitzky, "After the Hammer: Six Years of Meads v. Meads” (2019) 56:4 Alta L Rev 1167 at 1168 [Netolitzky, "Hammer"]; McRoberts, supra note 19 at 643.

Meads, supra note 17. The broad impact of this decision inside and outside Canada is reviewed in Netolitzky, "Hammer," ibid.

Unrau v National Dental Examining Board, 2019 ABQB 283 at paras 198-99 [Unrau]; Netolitzky, "History," supra note 18 at 641-42; Donald J Netolitzky, "Organized Pseudolegal Commercial Arguments [OPCA] in Canada; an Attack on the Legal System" (2016) 10 JPPL 137 at 189-90 [Netolitzky, "Attack"].

Unrau, ibid at paras 192-97, 753-60; Netolitzky, "Attack," ibid at 156-71.

Netolitzky, "Attack," ibid at 156-71; Perry, Hofmann \& Scrivens, supra note 18 at 45-58; John McCoy, David Jones \& Zoe Hastings, Building Awareness, Seeking Solutions: Extremism \& Hate Motivated Violence in Alberta (Edmonton: Organization for the Prevention of Violence, 2019) at 62-63, 70, online: $<$ preventviolence.ca/publication/building-awareness-seeking-solutions-2019-report/>.

Susan P Koniak, "When Law Risks Madness" (1996) 8:1 Cardozo Studies in L \& Literature 65 at 104-105; Netolitzky, "Rebellion," supra note 7 at 9-10.

Meads, supra note 17 at paras 302-50 reviews these many "Magic Hats."

Or that some courts are legitimate. Some OPCA litigants distinguish between courts that derive their authority from legislation (illegitimate) versus superior provincial courts of inherent common law jurisdiction (potentially legitimate). 
Pseudolaw practitioners are deeply, even obsessively, wedded to the idea of the rule of law, and that a court of some kind would mediate that law — their law. ${ }^{29}$ They simply structure those rules and boundaries of law and courts in a different, unorthodox, manner.

This law-centered perspective means OPCA litigants often litter their materials with citations and quotations of what they see as legitimate and binding authorities. Sometimes that includes court cases. Persons committed to pseudolaw do endorse a hierarchy of authorities. ${ }^{30}$ If one could illustrate that the Supreme Court of Canada, as the high court of Canada, has via its silence (and repeated silence) provided clear guidance about pseudolaw, then that non-response is a potential rebuttal to OPCA theories and arguments.

That inquiry is the primary purpose of this article. The authors identified 51 Supreme Court of Canada appeal applications filed between 1995 and 2018 by 46 persons, where evidence suggested those appeals were made on the basis of one or more OPCA concepts. All 51 applications were refused leave. Copies of the identified leave applications were obtained from the Supreme Court Registry, and then reviewed to determine:

1. the nature, subject, and scope of the appeal;

2. whether OPCA concepts that diverge from Canadian law were a basis for the appeal; and

3. if the appeal was grounded in pseudolaw, and if that divergence of pseudolaw from "mainstream" law hypothetically had merit, whether that, in the context of the appeal, satisfies the criteria for a successful leave application.

More succinctly, this investigation examines whether a leave application asks a question of pseudolaw that, if true or debatable, would be important enough that the Supreme Court should hear the appeal to provide clarity and guidance to all Canadian courts on that issue. If the Supreme Court instead refused leave, then that implies the question of pseudolaw has no merit.

An unanticipated additional issue emerged after an initial cohort of candidate Supreme Court leave applications were obtained and reviewed. As expected, some of the identified leave applications did advance points of pseudolaw that would, if true, fundamentally restructure important aspects of Canadian law. If those claims had merit, the Supreme Court should have granted leave.

The unexpected complication was certain leave applications were written in such a cryptic manner that the (pseudo)legal question the applicant intended to ask might not be comprehensible to a legally trained person who is unfamiliar with pseudolaw. That complication added an additional layer of analysis to this inquiry. Silence from the Supreme

Netolitzky, "Rebellion," supra note 7 at 9-10.

This hierarchy is sometimes unconventional, for example alleging that religious law has a superior rank or status (Meads, supra note 17 at paras 276-85; Potvin, supra note 17 at paras 102-34), or that a set of immutable rules called "common law" crystalized at an earlier point in history, and cannot be altered (Meads, supra note 17 at paras 326-30, Netolitzky, "Rebellion," ibid at 7-8; Netolitzky, "Magic," supra note 7 at 1071, 1073). 
Court would only be relevant if the point of (pseudo)law in dispute was both: (1) important enough to trigger Supreme Court of Canada intervention, and (2) framed in a manner that the Supreme Court could understand.

The second objective of this article is to investigate Canadian OPCA litigation in appellate courts. Most OPCA litigation occurs at the trial level; appellate OPCA decisions are usually perfunctory, or unreported. ${ }^{31}$ Data collected to evaluate the primary issue also provides the informational foundation for the first substantive evaluation of whether Canadian OPCA litigation is different in trial and appeal proceedings.

\section{Methodology}

\section{A. IDENTIFICATION OF STUdy GRouP LEAVE APPLications}

Prior investigation identified a total of 1089 reported Canadian court and tribunal decisions that relate to a dispute where a litigant employed OPCA concepts or displayed OPCA litigation indicia. ${ }^{32}$ These are the "OPCA Decision Dataset" or "Dataset."

Names of all OPCA litigants identified in the OPCA Decision Dataset were then searched in the Supreme Court of Canada's website Case Information docket search engine. ${ }^{33}$ This identified 71 candidate leave applications.

This methodology was not possible for 34 Dataset reported decisions where the litigants (1) had not been identified by name but instead only by letters or initials, (2) the OPCA litigant's identity was not established by other means, and (3) no associated appeal court case docket identifier was available. Thirty of these 34 decisions were family law matters that involved children. The remainder were a criminal conviction that reported sexual assaults by a Freeman-on-the-Land on minors ${ }^{34}$ a decision that evaluated whether a senior citizen had capacity, ${ }^{35}$ and a psychiatric review of a person detained for mental health reasons. ${ }^{36}$

One additional leave application with an apparent OPCA character was identified in earlier investigations by its atypical style of cause: "Natural and Sovereign Citizen(s): William-Grant: Fallis, :Reesa-Anita: Fallis and :Gary: Mosher v. Defacto Corporation of the Township of Cavan-Millbrook-North Monaghan." ${ }^{37}$ Related lower court proceedings were unreported.

Netolitzky, "Hammer," supra note 21 at 1203.

Donald J Netolitzky, "Organized Pseudolegal Commercial Arguments in Canadian Inter-Partner Family Law Court Disputes" (2017) 54:4 Alta L Rev 955 at 964-65 [Netolitzky, "Family"] describes the methodology used to identify the Dataset.

33 See Supreme Court of Canada, "SCC Case Information" (3 December 2012), online: $<$ scc-csc.ca/casedossier/info/search-recherche-eng.asp $\mathrm{x}>$.

$R \vee T L P, 2015$ BCSC 618, sentenced 2017 BCSC 1868.

SN et FL, 2013 QCCS 1018.

NM, 2011 CanLII 73645 (Ont CCB).

(29 April 2005), Toronto M32398 (ONCA), leave to appeal to SCC refused, 31004 (15 December 2005). 
A preliminary screen of these 71 applications evaluated whether pseudolaw was highly unlikely to be a basis for the Supreme Court appeal. Nine leave applications exhibited no evidence of pseudolaw issues in both the preceding appeal (court judgment or file records) and the Supreme Court of Canada docket case summary. This group of candidate applications was eliminated from the study.

An example of this category is Capilano Mobile Park v. Squamish Indian Band.$^{38}$ The British Columbia Court of Appeal decision indicated that OPCA concepts had been advanced at trial, but were then abandoned on appeal. The Supreme Court case summary ${ }^{39}$ lists only "conventional" legal issues.

Nine more applications were removed where the litigation subject and timing made an OPCA element highly unlikely. For example, six leave applications filed in the 1980s by Ontario resident John Alan Giagnocavo were excluded. The limited available record indicated that during this period Giagnocavo, a SRL, engaged in many Charter-related challenges to motor vehicle offences and legislation. Giagnocavo's leave applications were not investigated because OPCA litigants rarely claim Charter rights, ${ }^{40}$ and during this PreDetaxer period OPCA litigants in Canada were almost exclusively focused on evading tax obligations. $^{41}$

Two further Supreme Court appeals by Douglas Nagel ${ }^{42}$ and David Kevin Lindsay ${ }^{43}$ were excluded from the study because the appeals were incomplete. No leave application was filed.

The remaining 51 candidate leave applications were obtained from the Registrar and reviewed. This set of applications is the Study Group.

\section{B. INVESTIGATION OF STUDY GROUP LEAVE APPLICATIONS}

The Study Group applications were examined for pseudolaw concepts. This review was conducted broadly, and included not only the usual spectrum of OPCA concepts identified in Meads, but also schemes and motifs described in successor jurisprudence and United States and Canadian academic commentary. ${ }^{44}$

\section{$38 \quad 2016$ BCCA 437.}

39 See Supreme Court of Canada, "Summary: 37382" (2 May 2015), online: <scc-csc.ca/case-dossier/ info/sum-som-eng.aspx? cas $=37382>$.

40 Meads, supra note 17 at para 266. Recently in Canada, OPCA litigants have begun reframing their concepts to involve the Charter, for example: Pomerleau, supra note $12 ; R v$ White, 2017 BCPC 380 [White]; d'Abadie $v$ R, 2018 ABQB 298 [d'Abadie]. This is one of the few examples of innovation in pseudolaw theory in the past decade.

$41 \quad$ Netolitzky, "History," supra note 18 at 613-16.

42 Nagel vR,(29 November 2011), Ottawa, 34032 (SCC), online: <scc-csc.ca/case-dossier/info/dock-regieng.aspx? cas $=34032>$.

43 Lindsay v R, (12 April 1999), Ottawa, 27223 (SCC), online: <scc-csc.ca/case-dossier/info/dock-regieng.aspx? cas $=27223>$.

44 See Bank of Montreal v Rogozinsky, 2014 ABQB 771 [Rogozinsky]; Rothweiler v Payette, 2018 ABQB 288 at paras 6-21 [Rothweiler \#3] (Three/Five Letters); Crossroads-DMD Mortgage Investment Corporation v Gauthier, 2015 ABQB 703 (Bills of Exchange Act motifs); Servus Credit Union Ltd v Parlee, 2015 ABQB 700 [Servus] (WeRe Bank); Pomerleau, supra note 12 (international treaty "Strawman" theories). See also Netolitzky, "Hammer," supra note 21; Kalinowski, supra note 7. 
Pseudolaw concepts identified in a leave application were scored on several bases. First, each pseudolaw instance was evaluated to determine if it met the criteria on which a leave application may be granted. The Supreme Court Act provides broad discretion for the Supreme Court to hear appeals that raise issues of "public importance," that involve an important issue of law, or that are of "such a nature or significance as to warrant decision." 45 Authoritative commentary on this threshold is sparse. Most authorities cite the 10 April 1997 speech by Justice Sopinka as providing the relevant test, that leave is likely granted:

- for a constitutional challenge to legislation, common law, or government practices;

- when Canadian courts of appeal are in conflict;

- to respond to a novel point of law;

- to interpret language in a federal statute or multiple provincial statutes; and

- $\quad$ in relation to Aboriginal rights. ${ }^{46}$

If true or plausible, most pseudolaw concepts would be a basis on which to grant leave, since many OPCA motifs fundamentally re-order the operation of Canadian law, affect the operation of important legislation, or alter fundamental rights and legal principles.

However, in some instances, an OPCA concept may not be an issue under appeal, but instead appear as part of the leave application narrative, or in rhetoric and argument. Other OPCA motifs might only relate to alleged factual disputes. If true, the Supreme Court of Canada would by its rules not intervene in these circumstances. ${ }^{47}$

If an OPCA concept was the basis for an issue of law or mixed fact and law, and if true, that issue may be a basis on which to grant leave, then that pseudolaw concept was scored. It was rated in light of how that concept was presented via the leave application as a whole, on two bases, to what degree that issue:

1. is comprehensible to a legally trained person unfamiliar with pseudolaw; and

2. would affect Canadian law, if true.

The first rating is a "kisikawpimootewin Score" or "kS." The $\mathrm{kS}$ name derives from a 2004 Federal Court trial case, kisikawpimootewin v. Canada, ${ }^{48}$ where Justice Snider concluded a court and defendant had no obligation to respond to "a proceeding so ill-defined that it is

45 SCA, supra note $1, \mathrm{~s} 40(1)$.

46 Meehan et al, supra note 1 at Part 3:15, citing The Honourable Justice Henry S Brown, Supreme Court of Canada Practice 2015 (Toronto: Carswell, 2015) at 567.

$47 \quad$ Meehan et al, ibid.

482004 FC 1426 [kisikawpimootewin]. Quatloos! commentator Hilfskreuzer Möwe tentatively identified the plaintiff, kisikawpimootewin, as Kenneth Edward Jones, an Edmonton-area locksmith (Hilfskreuzer Möwe, "But enough of all this serious law-talking stuff..." (30 August 2013), posted on kisikawpimootewin - an exercise in Internet Archaelogy, online: <quatloos.com/Q-Forum/viewtopic. $\mathrm{php}$ t $=9526>$ ). Jones was, at a minimum, affiliated with contemporaneous Edmonton-area pseudolaw communities. 
unable to discern an argument, or identify any specific material facts" and when the defendant "is left both embarrassed and unable to defend itself." kisikawpimootewin" has subsequently been restated as the "Court has no obligation to respond to gibberish." 50

kisikawpimootewin is a particularly appropriate $\mathrm{kS}$ type model judgment as there is a strong possibility that the 2004 judgment itself illustrates the "kisikawpimootewin Effect": that a potentially valid action was dismissed because it was indecipherable. The kisikawpimootewin action is extensively documented on a website created by the plaintiff that tracks his litigation activities and reproduces documents sent to various government bodies and the Federal Court. ${ }^{51}$ While the kisikawpimootewin judgment does not appear to have drawn the attention of academic commentators, a detailed investigation by the OPCA critic and skeptic website Quatloos! $!^{52}$ suggests the plaintiff in kisikawpimootewin was advancing a weak but novel argument concerning the potential retroactive effect of legislation on Aboriginal rights. ${ }^{53}$ If so, then kisikawpimootewin is itself an illustration of the kisikawpimootewin Effect, where potentially meritorious litigation is rejected because a court does not understand the nature of the claim.

Pseudolaw issues identified in Study Group leave applications were each assigned a kS, using a six-point scale, where 0 indicates no unusual language, and 5 is a document that is practically impossible to understand.

$0=$ Orthodox: application uses no unorthodox or pseudolegal language or concepts.

$1=$ Pseudolaw and/or unorthodox language and concepts are present, but are clearly explained or defined by the applicant.

$2=$ Pseudolaw and/or unorthodox terms are present, can be readily detected, and their unusual character or meaning can be implied from the text.

$3=$ Pseudolaw and/or unorthodox concepts are present, but unexplained and unclear. This threshold is met where an ordinary legal term or concept is used in an unorthodox manner, and where a legally trained reader would plausibly not recognize that is the case.

$4=$ The leave application can only be understood by a reader who has a general familiarity with commonplace OPCA concepts. For example, the reader is assumed to understand the "Strawman" duality, and there is inadequate context or explanation of that motif. A trained lawyer unfamiliar with pseudolaw would be unable to comprehend aspects of the application and its intended meaning.

kisikawpimootewin, ibid at para 9.

Arabi v Alberta, 2014 ABQB 295 at para 85.

See online: Welcome to kisikawpimootewin and group(s) website! <signatoryindian.tripod.com>.

Quatloos!, online: <quatloosia.blogspot.com>, is a website dedicated to identification and criticism of scam and pseudolaw activities. Quatloos! is generally recognized as an expert forum for this subject area; see e.g. Meads, supra note 17 at para 655.

Hilfskreuzer Möwe, "For quite some time I have been very curious..." (27 August 2013), posted on kisikawpimootewin: An Exercise in Internet Archaelogy, online: <quatloos.com/Q-Forum/viewtopic.php $? \mathrm{t}=9526>$. 
$5=\quad$ The leave application can only be understood by someone with specialized and detailed knowledge of OPCA concepts. Without that background the leave application is indecipherable gibberish. An example of this category are documents written in the alternative grammar taught by US guru David Wynn Miller. ${ }^{54}$

For the purposes of this study, the Supreme Court of Canada will be plausibly unable to evaluate in a meaningful manner any leave application issue with a $\mathrm{kS}$ of 4 or 5 . This conservative presumption assumes that the Supreme Court does not have expertise in OPCA subject domains. Study Group applications with a kS of 4-5 are likely candidates for the kisikawpimootewin Effect, and therefore provide little evidence of Supreme Court perspective on the pseudolaw at issue.

However, where a pseudolaw issue receives a $\mathrm{kS}$ of $0-2$, then there is a strong basis to conclude the Supreme Court would understand the issue it was being asked to decide. Assigning an issue a $\mathrm{kS}$ of 3 may still mean the substance of an appeal issue might be understood. Denying leave potentially then has legal implications.

Meads was released on 19 September $2012 .{ }^{55}$ That development might affect implications of kS scores. Meads is the first convenient and broadly accessible resource that explains OPCA language and concepts. Once Meads is available, $\mathrm{kS}=3$ and possibly even $\mathrm{kS}=4$ issues would be much less likely to be affected by the kisikawpimootewin Effect.

Study Group leave application issues were also each assigned a "Disruption Score," or "DS." This six-point scale evaluates the effect a pseudolaw issue would have on "conventional" Canadian law, if the pseudolaw appeal issue were true. Put another way, DS measures the degree to which a pseudolaw issue potentially 'disrupts' the conventional legal order.

0 - No real effect on Canadian law. For example, a challenge to a finding of fact, or case-specific applications of a legal rule.

1 - Limited effect on Canadian law. The effect of the pseudolaw issue is largely restricted to the appellant, a small class, or an unusual or highly specialized scenario.

2 - Significant effects on an important principle of common law or legislation. For example, the pseudolaw issue alters who has an obligation to pay income tax.

3 - Broad effect on elements of Canadian law, legislation, and institutions. For example, the pseudolaw issue alleges the Income Tax Act is not valid legislation.

4 - Disruption to entire government or institutional operations, or a fundamental reordering of rights and freedoms. For example, criminal legislation and prohibitions

$54 \quad$ Netolitzky, "Magic," supra note 7 at 1061-63, 1084; McRoberts, supra note 19 at 638-40; Knutson (Re), 2018 ABQB 858 at paras 18-26 [Knutson].

$55 \quad$ Supra note 17. 
only operate where a person consents to be subject to government criminal law jurisdiction.

5 - The conventional constitutional order is revised or superseded. For example, the Magna Carta or Canadian Bill of Rights has supraconstitutional effect, or God's Law is supreme and trumps all Canadian law.

The Supreme Court would be unlikely to grant leave to a DS 0 or 1 issue, even if the pseudolaw challenge raised was true or plausible, because this is not the kind of issue where the Supreme Court intervenes and grants leave. A DS of 2 in most instances would warrant Supreme Court intervention, while DS of 3-5 represent issues that clearly are of potential national importance.

For this investigation, a highly relevant Study Group leave application issue is one that combines a low $\mathrm{kS}$ and a high DS. These are applications where a pseudolaw issue, if valid, is one that has significant implications to Canadian law, and where the application does not suffer from the kisikawpimootewin Effect.

Other variables recorded during review of the Study Group applications include:

(1) the date of the leave application;

(2) the source jurisdiction;

(3) reported lower court proceeding(s);

(4) whether lower court decisions were nonresponsive to the pseudolaw issues, for example dismissing the issues in brief reasons, or as gibberish, indecipherable, or nonsense;

(5) whether the appellant was represented or an SRL;

(6) if the appeal is:

(a) "offensive," and seeks to impose obligations on state or institutional actors,

(b) "defensive," and seeks to protect the appellant from state or institution action, detention, and legal obligations, or

(c) both "offensive" and "defensive";

(7) whether this is a civil or criminal appeal, and if the action falls into the four

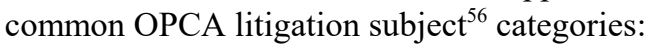

(a) no obligation to pay income tax, 
(b) a "get out of jail free" card,

(c) a "money for nothing" or debt elimination scheme, or

(d) a pseudolaw-based attack intended to force payments, benefits, or services;

(8) the OPCA movement and guru ${ }^{57}$ with whom the appellant is associated, if identifiable;

(9) the presence of unusual physical motifs, such as seals, multiple or atypical signatures, postage stamps, ink fingerprints, or blood;

(10) use of OPCA form documents;

(11) reliance on unorthodox pseudolaw-based authorities, such as vigilante tribunals and courts, or notaries acting as judges;

(12) a Sophistication Score (SS) of 1 to 5 to describe whether the leave application is a perfunctory or frivolous document, for example intended to simply cause delay ( $\mathrm{SS}=1$ ), ranging through to a carefully composed, organized, and researched leave application that accurately cites authorities and clearly establishes the issues in dispute and the appellant's arguments $(\mathrm{SS}=5)$;

(13) whether the leave application responds to Meads and other decisions that identify and reject the appellant's issues as pseudolaw and invalid;

(14) whether the leave application was dismissed;

(15) if costs were awarded against the leave applicant(s); and

(16) to what degree any Supreme Court of Canada Bulletin summary captures the substance of the leave application and issues.

\section{Example Study Group Leave Application Review}

A review of the Dalle Rive application ${ }^{58}$ illustrates this study's methodology. The application is a seven-page document that follows the Supreme Court of Canada leave application template. A number of pseudolaw motifs are obvious in the application:

1. Dalle Rive has adopted the "Strawman" duality, as explained above;

57 Meads, supra note 17 at paras 85-158, 168-98; Netolitzky, "History," supra note 18; Perry, Hofmann \& Scrivens, supra note 18; Netolitzky, "Hammer," supra note 21.

$58 \quad$ Dalle Rive 35874 , supra note 6. 
2. Dalle Rive argues he has already won this action because he obtained a "Certificate of Dishonour" via a Three/Five Letters process, ${ }^{59}$ which estops Canada from suing for taxes;

3. section 32 of the Canadian Charter of Rights and Freedoms $s^{60}$ means Canadian law only applies to government actors and employees, so Dalle Rive is not liable to pay income tax under the ITA; and

4. during a Tax Court of Canada proceeding the Canada Revenue Agency (CRA) has, as a precondition, a positive obligation to establish that an individual is a "taxpayer" and subject to the ITA; Dalle Rive is a private man and not a "taxpayer."

All four issues meet the minimum threshold of involving a question of law or mixed fact and law. Despite Dalle Rive frequently using language that invokes the "Strawman" duality and making a distinction between "private" versus "public" states, the "Strawman" motif is never explained in any manner, and instead that aspect of this application is highly cryptic. Issue one was therefore assigned a $\mathrm{kS}$ of 4 . The terminology associated with the Three/Five Letters issues is also not defined, but Dalle Rive's narrative provides enough background that a legally trained person would likely at least understand the gist of Dalle Rive's claim. This issue has a $\mathrm{kS}$ of 3 .

Issue three is clear and uses no atypical language, scoring a $\mathrm{kS}$ of 0 . Dalle Rive's claim that the CRA must prove jurisdiction is comprehensible, though it makes a pseudolegal distinction between private and public status. However, those terms are, to some degree, explained, warranting a $\mathrm{kS}$ of 2 .

All four issues have major implications to the conventional Canadian legal order, warranting DS of 4, 3, 4, and 3, respectively.

These results imply that the unsuccessful Dalle Rive leave application is a safe basis to conclude the Supreme Court rejected issues three and four, and a plausible basis to reject the Three/Five Letters foisted unilateral agreement scheme. The "Strawman" issue has fallen prey to the kisikawpimootewin Effect, and is incomprehensible to a legally trained professional unfamiliar with OPCA theory.

Dalle Rive explicitly identifies OPCA jurisprudence, including Meads, and says it was an error of law for the trial court to assume the "association" ${ }^{61}$ of Dalle Rive with those cases. This is, to be generous, a superficial rebuttal.

The Dalle Rive application is generally well-written, but its poor use of references rates a SS of 2. Dalle Rive cites both conventional and unconventional sources. The Canadian case citations indicate either a poor understanding of the jurisprudence, or that Dalle Rive had copied someone else's materials without evaluating the accuracy of those citations. For 
example, Dalle Rive at paragraph 3 claims that the CRA has a positive obligation to establish a prima facie case that he owes tax, and then cites McMillan v. Her Majesty the Queen, ${ }^{62} \mathrm{R}$. $v$. Stinchcombe, ${ }^{63}$ and Roncarelli v. Duplessis. ${ }^{64}$ McMillan, in fact, stands for exactly the opposite, and affirms that a Tax Court of Canada appellant has an initial positive obligation to "demolish" 65 the Minister's assumptions. Stinchcombe involves Crown criminal law disclosure obligations, and has nothing to do with tax proceedings. Roncarelli is also irrelevant.

Dalle Rive relies on both legislation and five "Maxims of Law." The latter are a common purported foundation for OPCA concepts. ${ }^{66}$ The so-called "Maxims" are spurious, for example "An unrebutted affidavit stands as truth in commerce" and "An un-rebutted affidavit becomes the judgment in commerce." These "Maxims" are derived from US pseudolaw theory and, ultimately, a misconception that the Bible provides supraconstitutional legal principles. $^{67}$

Aside from the "Strawman" motifs, Dalle Rive's application is largely conventional, with the exception that Dalle Rive affirmed this document before a Notary Public with an unusual and unnecessary notarial act. Dalle Rive's concepts suggest a Freeman-on-the-Land affiliation. $^{68}$

\section{RESUltS}

For consistency and ease of reference, Study Group leave applications are identified by the last name of the first appellant and the Supreme Court of Canada docket number. For example, "Dove 37487" refers to the Wally Dove v. Her Majesty the Queen leave application assigned Supreme Court of Canada docket 37487. Following the approach in Meads, ${ }^{69}$ two leave applications filed by Sean Wesley Henry are identified by that name rather than Henry's OPCA nom de plume: “:Nanya-Shaabu:El.” Luc Bernard d'Abadie initiated two separate sequential appeals, dockets 37507 and 37508, but these were then advanced together via one leave application, which is identified as d'Abadie 37507/8.

\section{6 .}

$66 \quad$ Rothweiler v P

2012 FCA 126 at para 7 [McMillan].

[1991] 3 SCR 326 [Stinchcombe].

[1959] SCR 121 [Roncarelli].

Netolitzky, "Magic," ibid. UCBneuaJkoQH52hvvEvITwfg>.

Supra note 17 at para 7 .

See Elio Dalle Rive, online: < facebook.com/elio.rive>; Elio Dalle Rive, online: <youtube.com/channel/ 
Figure 1 illustrates the temporal distribution of the Study Group leave applications in relation to the Dataset's reported OPCA-related decisions.

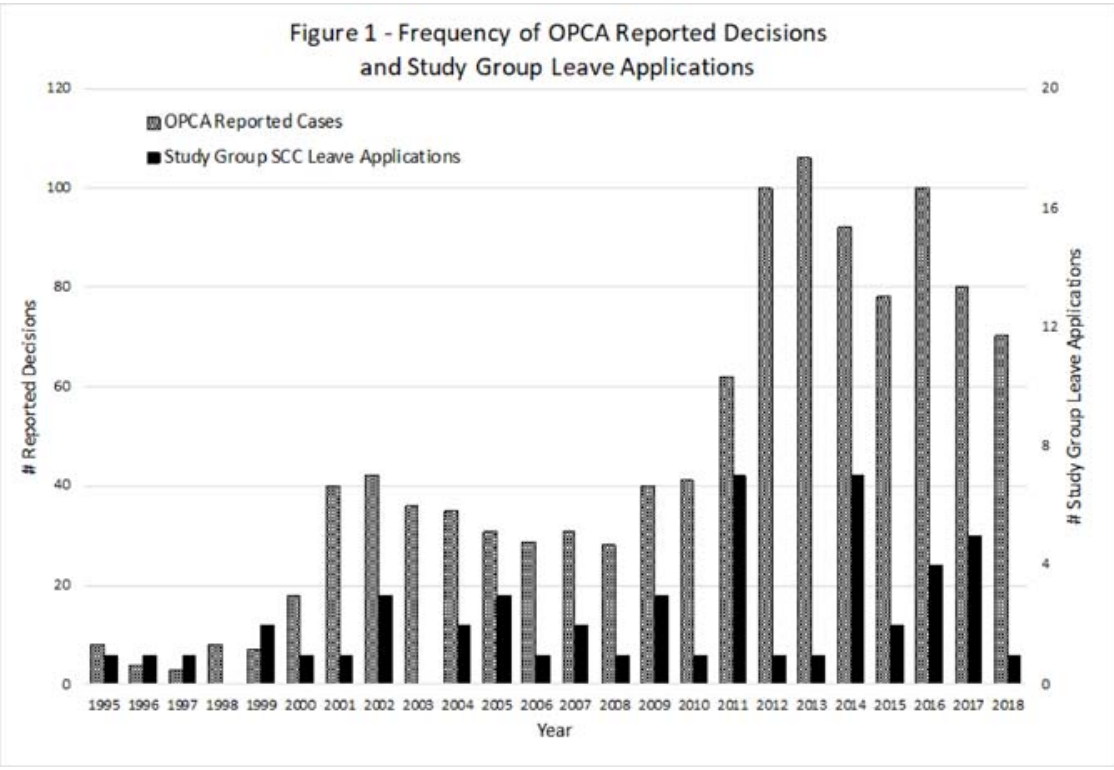

Figure 1: incidence from 1995-2018 of OPCA-related reported Canadian court and tribunal decisions, and Study Group Supreme Court of Canada leave applications.

The majority of Study Group leave applications ( 82.3 percent, $n=42$ ) were filed by SRLs.

All 51 leave applications were denied leave.

41.2 percent $(\mathrm{n}=21)$ of the Study Group applications attempted to impose a legal obligation on the respondent(s), while 70.6 percent $(n=36)$ attempted to defend against a legal obligation. ${ }^{70}$

Study Group applications were split 72.5 percent civil, 27.5 percent criminal $(\mathrm{N}=51)$.

Table 1 illustrates that the four most common litigation subjects identified in Dataset judgments ${ }^{71}$ were also present in the Study Group with a high frequency. 
TABLE 1: FREQUENCY OF

COMMONPLACE LITIGATION SUBJECTS

\begin{tabular}{|c|c|c|}
\hline \multicolumn{3}{|c|}{ Table 1A: Litigation Type } \\
\hline Litigation Subject & $\begin{array}{l}\text { Dataset Judgments } \\
\quad(\mathrm{N}=1089)\end{array}$ & $\begin{array}{l}\text { Study Group } \\
\text { Applications } \\
\quad(\mathbf{N}=51)\end{array}$ \\
\hline $\begin{array}{l}\text { "Get out of jail free" card for criminal accused, detained, and/or } \\
\text { incarcerated persons. }\end{array}$ & $39.0 \%(n=378)$ & $29.4 \%(\mathrm{n}=15)$ \\
\hline Eliminate any obligation to pay income tax. & $19.9 \%(n=192)$ & $31.4 \%(n=16)$ \\
\hline Create "money for nothing" or nullify debts. & $12.5 \%(n=121)$ & $13.7 \%(n=7)$ \\
\hline Attack and/or restrain government and institutional actors. & $13.8 \%(n=133)$ & $39.2 \%(\mathrm{n}=20)$ \\
\hline \multicolumn{3}{|c|}{ Table 1B: OPCA Movement } \\
\hline Litigation Subject & $\begin{array}{c}\text { Detaxer/Pre-Detaxer } \\
\text { Applications } \\
(\mathbf{N}=\mathbf{3 0})\end{array}$ & $\begin{array}{c}\text { Freeman-on-the-Land } \\
\text { Applications } \\
(\mathbf{N}=12)\end{array}$ \\
\hline $\begin{array}{l}\text { "Get out of jail free" card for criminal accused, detained, and/or } \\
\text { incarcerated persons. }\end{array}$ & $26.7 \%(\mathrm{n}=8)$ & $41.7 \%(\mathrm{n}=5)$ \\
\hline Eliminate any obligation to pay income tax. & $46.7 \%(n=14)$ & $8.7 \%(n=1)$ \\
\hline Create "money for nothing" or nullify debts. & $3.3 \%(\mathrm{n}=1)$ & $25 \%(n=3)$ \\
\hline Attack and/or restrain government and institutional actors. & $6.7 \%(\mathrm{n}=2)$ & $75 \%(n=9)$ \\
\hline
\end{tabular}

Table 1: frequency at which four common OPCA litigation subjects appear in: (A) the Dataset judgments and Study Group leave applications, and (B) Study Group leave applications originating from Pre-Detaxer and Detaxer versus Freeman-on-the-Land OPCA movements. Certain Dataset judgments and Study Group leave applications exhibit more than one of these four litigation subjects.

Four study group applications were not suitable for further investigation:

- $\quad$ Blerot 27819 and Blerot 28907 allege the Saskatchewan Court of Appeal made procedural errors. Neither leave application provides sufficient facts for the Supreme Court of Canada to conduct a reasoned evaluation of the alleged issue(s). Both applications appear to involve only dispute-specific question(s) (to the degree these are identified), so this litigation has no potential general application.

- McElheran 29372 is an indecipherable 16-page application, which alleges some kinds of procedural impropriety and persecution of McElheran in Alberta courts. McElheran denounces a conspiracy of politicians, the courts, and government actors, all directed by the International Monetary Fund and World Bank. This conspiracy's intentions are "structural adjustment programs" to cause "genocide upon various nations." 72 The McElheran 29372 application did not provide any issue that could be assigned $\mathrm{kS}$ and $\mathrm{DS}$ values.

- Wadhams 35885 is an incoherent application that alleges that, in some manner, the appellant had an Aboriginal right to commercial fisheries, and the state actors' 
actions were "ultra virus."73 The only potential issue on appeal was the validity of section 839(1) of the Criminal Code, which prohibits further appeal where a summary conviction appeal is denied leave by a provincial court of appeal. No issue that could be assigned a $\mathrm{kS}$ and DS was identified.

Of the 47 remaining applications, 16 were entirely conventional, and are summarized in Table 2.

TABLE 2: SUMMARY OF

NON-OPCA STUDY GROUP APPLICATIONS

\begin{tabular}{|c|c|c|c|c|c|}
\hline $\begin{array}{c}\text { Leave } \\
\text { Applications }\end{array}$ & Appeal Issue(s) & Lawyer or SRL & Costs & DS & SS \\
\hline \multirow[t]{2}{*}{ Ambrosi 35979} & $\begin{array}{l}\text { Criminal Code private information section } 507.1 \text { hearings are in camera and ex } \\
\text { parte, so is the Attorney General prohibited from contacting the accused? }\end{array}$ & SRL (Lindsay) & None & 2 & 5 \\
\hline & What is the correct interpretation of Criminal Code, section $337 ?$ & & & 2 & 5 \\
\hline Dick 29128 & $\begin{array}{l}\text { What are the circumstances and criteria that disqualify a layperson agent from } \\
\text { representing an accused in a criminal action? }\end{array}$ & SRL (Lindsay) & No data & 2 & 4 \\
\hline Kennedy 31229 & $\begin{array}{l}\text { Is the mens rea of tax evasion negated where a taxpayer honestly believed income } \\
\text { tax is unconstitutional? }\end{array}$ & SRL & No data & 3 & 3 \\
\hline Klundert 30578 & & Christie, Douglas & None & 3 & 4 \\
\hline Ricci 30684 & & Christie, Douglas & None & 3 & 4 \\
\hline Klundert 32936 & $\begin{array}{l}\text { Is the mens rea of tax evasion negated where the taxpayer intentionally failed to } \\
\text { pay tax, but knew the CRA would inevitably collect? }\end{array}$ & Christie, Douglas & None & 3 & 5 \\
\hline \multirow[t]{2}{*}{ Klundert 34558} & $\begin{array}{l}\text { Is the mens rea of tax evasion negated where a person chooses to be a "tax } \\
\text { protestor" and not pay tax, but knew the CRA would inevitably collect? }\end{array}$ & Christie, Douglas & None & 3 & 5 \\
\hline & Should a juror have been dismissed? & & & 0 & 5 \\
\hline Klundert 35996 & $\begin{array}{l}\text { Can a taxpayer challenge the quantum of evaded taxes and Charter compliance of } \\
\text { searches in an income tax appeal after conviction for tax evasion? }\end{array}$ & SRL & $\begin{array}{l}\text { Costs: } \\
\$ 947.76\end{array}$ & 1 & 4 \\
\hline Klundert 35997 & $\begin{array}{l}\text { When the CRA seizes funds under a jeopardy order are those funds prioritized to } \\
\text { satisfy criminal tax evasion penalties? }\end{array}$ & SRL & Costs & 1 & 4 \\
\hline Lewry 34898 & $\begin{array}{l}\text { Where legislation authorizes alternative search procedures, is the more "searchee- } \\
\text { friendly" version required by the Charter? }\end{array}$ & SRL & $\begin{array}{l}\text { Costs: } \\
\$ 1531.26\end{array}$ & 3 & 4 \\
\hline Lindsay 26150 & Does access to justice require state funding of court transcripts? & SRL & None & 2 & 5 \\
\hline Lindsay 27181 & Is in forma pauperis status a binding common law principle? & SRL & None & 2 & 4 \\
\hline Lindsay 31465 & Was a litigant's detention for a hearing lawful? & SRL & No data & 1 & 3 \\
\hline Long 34280 & $\begin{array}{l}\text { Are a taxpayer's disclosure obligations in a Tax Court of Canada appeal affected if } \\
\text { disclosure established criminal activities and would self-incriminate? }\end{array}$ & SRL (Lindsay) & $\begin{array}{l}\text { Costs: } \\
\$ 974.98\end{array}$ & 2 & 5 \\
\hline Smith 25080 & $\begin{array}{l}\text { What is the appropriate method to calculate an annual interest rate when payments } \\
\text { and interest are due on a higher frequency? }\end{array}$ & $\begin{array}{l}\text { Cowtan, Margaret } \\
\text { A }\end{array}$ & Costs & 1 & 5 \\
\hline \multirow[t]{2}{*}{ Watts 38141} & Does the Interpretation Act preclude tax-related searches under the Criminal Code? & SRL & No data & 2 & 3 \\
\hline & $\begin{array}{l}\text { Does Criminal Code, section } 380 \text { (1) (fraud) offend Charter sections } 7 \text { and } 11 \\
\text { because it inadequately describes the mens rea of the offence? }\end{array}$ & & & 2 & 3 \\
\hline
\end{tabular}

Table 2: summary of Study Group applications that did not include OPCA issues. Kennedy 31229, Klundert 30578, and Ricci 30684 involve the same issue. All application issues are $\mathrm{kS}=0$. "SRL (Lindsay)" indicates an application where David Kevin Lindsay was likely involved in preparation of the leave application. Costs: "Costs" indicates costs were awarded but the quantum is not indicated; "No data" indicates the Supreme Court of Canada docket record does not identify whether costs were or were not awarded. 
Though the Ambrosi 35979 and Long 34280 applications were filed by the appellants, both these individuals collaborated with OPCA guru David Kevin Lindsay in lower court proceedings, ${ }^{74}$ and these leave applications included idiosyncratic formatting elements only found in contemporaneous leave applications filed by Lindsay personally. As indicated in Table 2, this leads to a strong suspicion that Lindsay prepared these two applications. Dick 29128 explicitly states Lindsay prepared the appeal materials, and acted as the agent of record.

The remaining 31 Study Group leave applications involved at least one OPCA-specific issue.

Prior commentary has proposed that pseudolaw exists and has spread internationally as the "Pseudolaw Memeplex," a kind of alternative legal system that has six key components. ${ }^{75}$ Table 3 illustrates the majority (37 of 55, 67.3 percent) of OPCA issues identified in the Study Group leave applications fall within five components of the six-part Pseudolaw Memeplex schema. No examples of the "legal action requires an injured party" Pseudolaw Memeplex concept category were identified in the Study Group leave applications.

TABLE 3: STUDY GROUP

\section{Pseudolaw MeMePleX OPCA CONCEPTS}

\begin{tabular}{|c|c|c|c|c|}
\hline $\begin{array}{c}\text { Core Pseudolaw } \\
\text { Component }\end{array}$ & Specific OPCA Issue Argued & $\begin{array}{c}\text { Leave } \\
\text { Application(s) }\end{array}$ & $\mathbf{k S}$ & DS \\
\hline $\begin{array}{l}\text { All relationships } \\
\text { are based on } \\
\text { agreement, } \\
\text { including state } \\
\text { authority and } \\
\text { legislation }\end{array}$ & $\begin{array}{l}\text { An individual, as a private person, may unilaterally reject title, "person at } \\
\text { law" status, and state and court authority. } \\
\text { Governments obtain their authority via a contract. } \\
\text { An individual may refuse to associate with Canada, a "federal juristic unit," } \\
\text { since that association is slavery. } \\
\text { The Coronation Oath is a contract to enforce the King James Bible. } \\
\text { The interrelationship between two private individuals is defined solely by } \\
\text { terms of a contract. }\end{array}$ & $\begin{array}{l}\text { Thompson } 36111 \\
\text { Williams } 33209 \\
\text { Williams } 33211 \\
\text { d'Abadie } 37507 / 8 \\
\text { Medd } 29414 \\
\text { Ste-Marie } 37452 \\
\text { Dove } 37487 \\
\text { Lindsay } 34331 \\
\text { Drosdovech } 33143\end{array}$ & $\begin{array}{l}4 \\
4 \\
4 \\
0 \\
0\end{array}$ & $\begin{array}{l}4 \\
4 \\
4 \\
4\end{array}$ \\
\hline $\begin{array}{l}\text { Silence means } \\
\text { agreement in } \\
\text { contract, disputes, } \\
\text { and evidence }\end{array}$ & $\begin{array}{l}\text { Silence accepts a contract offer. } \\
\text { Silence after accepting a partial payment accepts a contract offer. } \\
\text { Three/Five Letters foisted unilateral agreements block collection of income } \\
\text { tax. } \\
\text { Penalties may be imposed by Three/Five Letters foisted unilateral } \\
\text { agreements. } \\
\text { Government actors by their silence accept penalties set by a "fee schedule" } \\
\text { foisted unilateral agreement. } \\
\text { Failure to rebut allegations proves the plaintiff's case. } \\
\text { Failure to rebut a Youtube video proves the plaintiff's case. } \\
\text { Failure to respond to an affidavit proves facts by "tacit consent." }\end{array}$ & $\begin{array}{l}\text { Reckless } 36356 \\
\text { Reckless } 36356 \\
\text { Dalle Rive } 35874 \\
\text { Ste-Marie } 37452 \\
\text { Thompson } 36111 \\
\text { Henry } 34172 \\
\text { Williams } 33209 \\
\text { Henry } 33994 \\
\text { Henry } 34172 \\
\text { Williams } 33209\end{array}$ & $\begin{array}{l}3 \\
2 \\
4 \\
2 \\
2 \\
4\end{array}$ & $\begin{array}{l}1 \\
3 \\
4 \\
3\end{array}$ \\
\hline
\end{tabular}




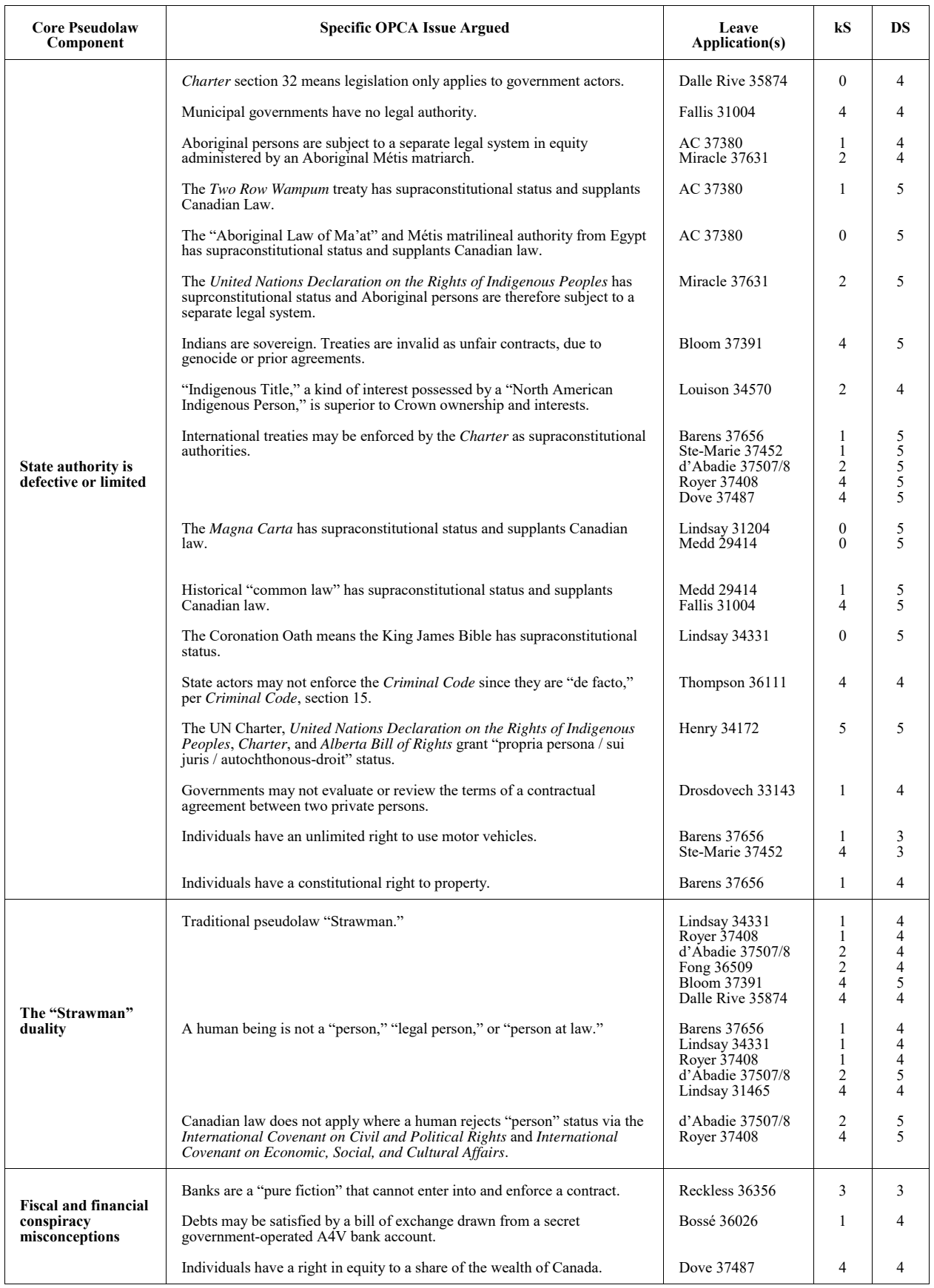

Table 3: OPCA concepts identified in the Study Group leave applications that are aspects of the six core elements of the US Sovereign Citizen-derived Pseudolaw Memeplex. ${ }^{76}$ 
The remaining OPCA issues that were not aspects of the Pseudolaw Memeplex's six core concepts were further divided into two groups: (1) issues that directly relate to income tax, and (2) other topics. These OPCA issue groups are summarized in Tables 4 and 5, respectively.

The majority of tax-specific OPCA issues summarized in Table 4 relate to the validity and enforceability of the ITA, and thus whether or not income tax obligations exist at all.

TABLE 4: INCOME TAX SPECIFIC

STUDY GROUP OPCA CONCEPTS

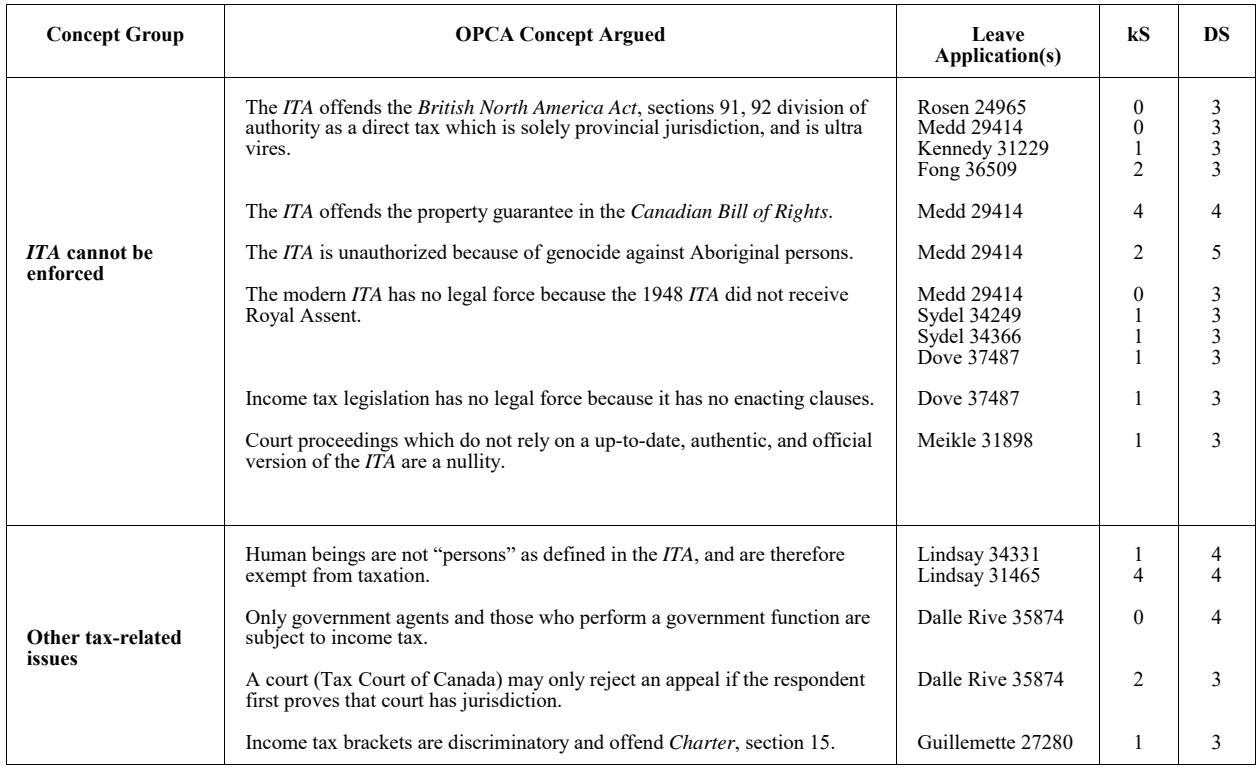

Table 4: OPCA concepts identified in the Study Group leave applications that relate only to the ITA and potential liability to pay income tax.

Meikle 31898 was very likely prepared by Lindsay since Lindsay assisted Meikle in lower court proceedings, ${ }^{77}$ and Meikle 31898 has Lindsay-specific formatting motifs.

The remaining miscellaneous OPCA-related issues itemized in Table 5 largely involve challenges to judicial authority, and questions that involve court procedure and processes. 


\section{TABle 5: OTher StUdy Group \\ OPCA CONCEPTS}

\begin{tabular}{|c|c|c|c|c|}
\hline Concept Group & OPCA Concept Argued & $\begin{array}{c}\text { Leave } \\
\text { Application(s) }\end{array}$ & kS & DS \\
\hline Judicial authority & $\begin{array}{l}\text { Judges must disclose their memberships in criminal organizations such as } \\
\text { the Freemasons, then recuse themselves. } \\
\text { Judges who fail to gown have no authority. } \\
\text { Judges who do not provide their Oath of Office on demand have no } \\
\text { authority. }\end{array}$ & $\begin{array}{l}\text { Sydel } 34249 \\
\text { Sydel } 34366 \\
\\
\text { Henry } 33994 \\
\text { Lindsay } 34331\end{array}$ & $\begin{array}{l}1 \\
1 \\
0 \\
0\end{array}$ & $\begin{array}{l}2 \\
2 \\
1 \\
2\end{array}$ \\
\hline $\begin{array}{l}\text { Court procedures } \\
\text { and processes }\end{array}$ & $\begin{array}{l}\text { Common Law and the Magna Carta guarantee jury trials as an absolute } \\
\text { right. } \\
\text { Charging fees for transcripts offends the Magna Carta. } \\
\text { Vexatious litigant court access restrictions offend international law, the } \\
\text { Charter, and the Alberta Bill of Rights. }\end{array}$ & $\begin{array}{l}\text { Medd } 29414 \\
\text { Lindsay } 31204 \\
\text { Henry } 34172\end{array}$ & $\begin{array}{l}0 \\
2\end{array}$ & $\begin{array}{l}3 \\
3\end{array}$ \\
\hline Other issues & $\begin{array}{l}\text { The US Uniform Commercial Code is a binding authority in Canada. } \\
\text { Banks have no right to foreclose and take title to "unseeded" Indian land. }\end{array}$ & $\begin{array}{l}\text { Reckless } 36356 \\
\text { Hlatky } 35408\end{array}$ & $\begin{array}{l}3 \\
2\end{array}$ & 4 \\
\hline
\end{tabular}

Table 5: OPCA concepts identified in the Study Group leave applications that were neither aspects of the US Sovereign Citizen-derived Pseudolaw Memeplex, nor related only to the ITA and liability to pay income tax.

Most leave applications appear to have been genuine, serious efforts to access the Supreme Court of Canada, which is reflected in a high average SS of $3.13(\mathrm{~N}=51)$. Figure 2 compares the SS of applications filed by SRLs and lawyers. Figure 3 compares the SS of SRL applicants who belong to the Pre-Detaxer and Detaxer movements to applicants with a Freemen-on-the-Land affiliation.

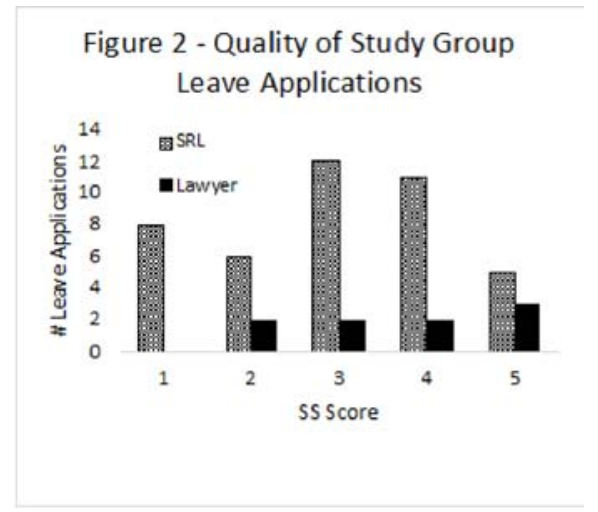

Figure 2: distribution of SS (Sophistication Scores) for Study Group leave applications filed by lawyers $(\mathrm{N}=9)$ and SRLs $(\mathrm{N}=42)$. 


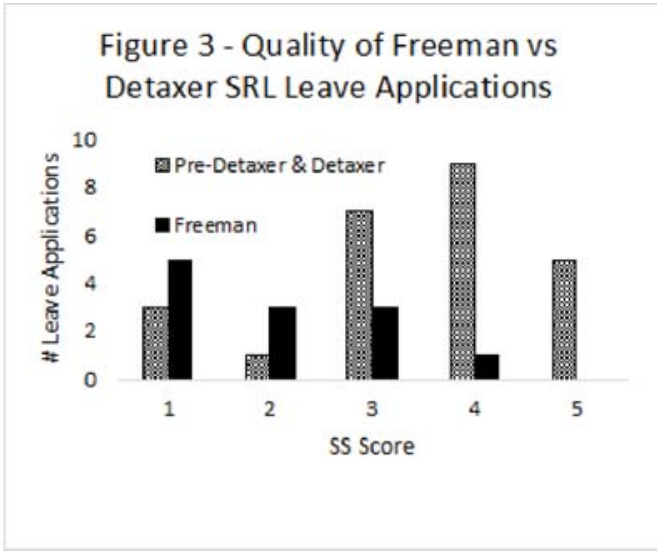

Figure 3: distribution of SS (Sophistication Scores) for Study Group leave applications filed by SRLs affiliated with the Freeman-on-the-Land ( $\mathrm{N}=12)$, and Pre-Detaxer and Detaxer $(\mathrm{N}=25)$ movements.

Figure 4 illustrates the DS range for OPCA issues identified in the Study Group. The average score for this population was $3.74(\mathrm{~N}=86)$.

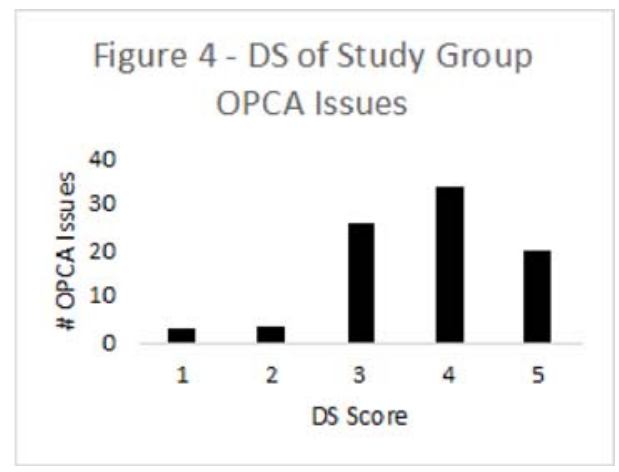

Figure 4: DS (Disruption Scores) for OPCA issues identified in Study Group leave applications $(\mathrm{N}=86)$.

Where docket data was available, ${ }^{78}$ unfavourable cost awards were made against the appellant in 53.8 percent $(\mathrm{N}=39)$ of Study Group applications. OPCA arguments slightly increased the frequency of costs against the appellant: 58.6 percent $(\mathrm{N}=23)$. Elevated solicitor-client costs were only ordered in response to one Study Group appeal, Henry 33994 $(\$ 6,739.32)$.

Caution should be exercised in relying upon quantitative data reported in this investigation. First, the Study Group population is small and a poor candidate for statistical

78 The Supreme Court of Canada docket records provided no data relating to costs for 12 Study Group leave applications. 
analysis. Second, the Study Group is very likely incomplete and plausibly exhibits significant bias due to its reliance on the Dataset as a primary search mechanism. ${ }^{79}$ Leave applications were largely identified via candidate appellant names derived from a collection of reported cases that involve OPCA motifs. For example, this methodology would not identify Supreme Court of Canada OPCA-based leave applications where no lower court decisions were reported.

\section{ANALYSIS}

This investigation establishes that the Supreme Court of Canada has been broadly exposed to OPCA concepts via Study Group leave applications.

The Supreme Court's silence is telling, particularly given the very high DS assigned to identified OPCA issues (Figure 4). Put another way, the Study Group leave applications seek to radically rework Canadian law, typically shifting authority towards individuals. ${ }^{80}$ If these concepts had merit, the Supreme Court should have responded. It has not.

\section{A. Implicitly ReJected PSEUdolaw MOTIFS AND CONCEPTS}

The Study Group leave applications presented the Supreme Court of Canada with many OPCA concepts and motifs in a comprehensible manner. All leave applications that included OPCA concepts were denied leave to appeal. Combined, these observations create a strong inference that the Supreme Court has concluded certain OPCA issues are not of national relevance, given those issues' low kS to high DS ratios. These OPCA concepts are therefore implicitly rejected as legally incorrect.

Though Canadian pseudolaw may at first appear to include a bewildering range of ideas and motifs, the Pseudolaw Memeplex applied by OPCA communities worldwide can be reduced to six fundamental core concepts:

1. everything is a contract;

2. silence means acceptance or agreement;

3. the law may only act where there is an injured party;

4. $\quad$ state authority is defective or limited;

5. the "Strawman" duality; and

6. financial and monetary theory "money for nothing" schemes. ${ }^{81}$ 
As previously indicated, the third core concept, that an injured party is required for legal action, was not detected in any of the Study Group applications.

However, the other five core Pseudolaw Memeplex concepts were implicitly considered and rejected when the Supreme Court of Canada refused leave to the OPCA-based Study Group applications identified in Table 6.

TABLE 6: IMPLICITLY REJECTED

PSEudolaw Memeplex CoRe Concepts

\begin{tabular}{|c|c|c|c|c|}
\hline Concept Group & OPCA Concept Argued & $\begin{array}{c}\text { Leave } \\
\text { Application(s) }\end{array}$ & kS & DS \\
\hline $\begin{array}{l}\text { Everything is a } \\
\text { contract }\end{array}$ & $\begin{array}{l}\text { Government authority requires consent. } \\
\text { King James Bible is a contractual authority binding on government. } \\
\text { Contract terms define the relationship between two persons. }\end{array}$ & $\begin{array}{l}\text { Thompson } 36111 \\
\text { d'Abadie } 37507 / 8 \\
\text { Lindsay } 34331 \\
\text { Drosdovech } 33143\end{array}$ & $\begin{array}{l}2 \\
2 \\
0 \\
1\end{array}$ & $\begin{array}{l}5 \\
4\end{array}$ \\
\hline $\begin{array}{l}\text { Silence means } \\
\text { acceptance or } \\
\text { agreement }\end{array}$ & $\begin{array}{l}\text { In contract. } \\
\text { Versus allegations or claimed facts. }\end{array}$ & $\begin{array}{l}\text { Reckless } 36356 \\
\text { Ste-Marie } 37452 \\
\text { Henry } 33994 \\
\text { Henry } 34172\end{array}$ & $\begin{array}{l}0 \\
2 \\
2 \\
2\end{array}$ & $\begin{array}{l}3 \\
4 \\
3 \\
3\end{array}$ \\
\hline $\begin{array}{l}\text { State authority is } \\
\text { defective or limited }\end{array}$ & $\begin{array}{l}\text { Legislation only applies to government actors. } \\
\text { Aboriginal persons are outside Canadian law or have special status. } \\
\text { International treaties have supraconstitutional status. } \\
\text { Historical and pre-Confederation aspects of English law and legal } \\
\text { traditional have supraconstitutional status. } \\
\text { Private contracts are immune to government review or scrutiny. }\end{array}$ & $\begin{array}{l}\text { Dalle Rive } 35874 \\
\text { AC } 37380 \\
\text { Miracle } 37631 \\
\text { Louison } 34570 \\
\text { Barens } 37656 \\
\text { Ste-Marie } 37452 \\
\text { d'Abadie } 37507 / 8 \\
\text { Miracle } 37631 \\
\text { Lindsay } 31204 \\
\text { Lindsay } 34331 \\
\text { Medd } 29414 \\
\text { Drosdovech } 33143\end{array}$ & $\begin{array}{c}0 \\
0-1 \\
1-2 \\
2 \\
1 \\
1 \\
2 \\
2 \\
0 \\
0 \\
0 \\
1\end{array}$ & $\begin{array}{c}4 \\
\\
4-5 \\
4-5 \\
5 \\
5 \\
5 \\
5 \\
5 \\
5 \\
5 \\
5 \\
4\end{array}$ \\
\hline $\begin{array}{l}\text { The "Strawman" } \\
\text { duality }\end{array}$ & $\begin{array}{l}\text { A human being is not a "person," "legal person," or "person at law." } \\
\text { The "Strawman" and government authority may be rejected via } \\
\text { international treaties. }\end{array}$ & $\begin{array}{l}\text { Lindsay } 34331 \\
\text { Royer } 37408 \\
\text { d"Abadie } 37507 / 8 \\
\text { Fong } 36509 \\
\text { Barens } 37656 \\
\text { Lindsay } 34331 \\
\text { Royer } 37408 \\
\text { d"Abadie } 37507 / 8 \\
\text { d'Abadie } 37507 / 8\end{array}$ & $\begin{array}{l}1 \\
1 \\
2 \\
2 \\
\\
1 \\
1 \\
1 \\
2 \\
\\
2\end{array}$ & $\begin{array}{l}4 \\
4 \\
4 \\
4 \\
\\
4 \\
4 \\
4 \\
4 \\
5 \\
\end{array}$ \\
\hline $\begin{array}{l}\text { Financial } \\
\text { conspiracy } \\
\text { misconceptions }\end{array}$ & $\begin{array}{l}\text { Debts may be satisfied by a bill of exchange drawn from a secret } \\
\text { government-operated A4V bank account. }\end{array}$ & Bossé 36026 & 1 & 4 \\
\hline
\end{tabular}

Table 6: Core OPCA Pseudolaw Memeplex ${ }^{82}$ concepts implicitly rejected by the denial of leave to identified Study Group leave applications, identified by low kS to high DS ratios. 
Importantly, these results refute "Strawman" theory. ${ }^{83}$ The "Strawman" is the keystone of the modern Pseudolaw Memeplex, and, post-2000, has been relied upon by all guru promoters in Canada. ${ }^{84}$

The "Strawman" duality centers on the belief that a human being is not born with a "legal" aspect. Humans and their legal character are instead distinct, separate, and separable parts. The "Strawman" legal aspect, often called the "person" or "legal person," is a non-human non-corporeal entity identified by the human's name in all upper case letters. The "person" is attached to a child via birth documentation, which is a kind of contract.

This human versus "Strawman" "person" distinction is often expressed as "I am not a person, but I have a person.",

"Strawman" theory claims government, police, and courts have no inherent authority over human beings ("state authority is defective or limited"). The authority exercised by conventional authorities "chains" its way through the "Strawman" to the human being via the birth documentation contract ("everything is a contract"). Though the child or his parents presumably had no idea of the implications of that birth documentation, their failure to object permits otherwise voluntary state influence ("silence means acceptance or agreement").

This erroneous belief that the authority of state actors and the binding character of legislation only flows from contract ("everything is a contract") also provides the mechanism by which pseudolaw adherents are taught they may escape government authority. All they need to do is end the "Strawman" birth documentation contract by withdrawing their consent to be governed ("everything is a contract").

The usual mechanism to do that is a unilateral written declaration that the pseudolaw adherent has terminated all contractual relationships with governments, police, and the courts. Robert Arthur Menard, the founder and guru of the Canadian Freeman-on-the-Land movement, called this document a "Notice of Understanding, Intent, and Claim of Right" (NOUICR). ${ }^{86}$ A NOUICR includes a clause that the NOUICR is deemed to be accepted and in force unless its claims are rebutted within a certain time period ("silence means acceptance or agreement"').

The leave applications and implicitly rejected issues identified in Table 6 establish that the entire "Strawman" Theory narrative is incompatible with Canadian law. First, arguments that a human being is separate from his or her legal character have repeatedly been implicitly rejected. As mentioned earlier, historical English law did at one point recognize humans who had no legal personality. This specific fact is raised in Lindsay $34331 .^{87} \mathrm{In}$ modern law, any human being is also innately a legal person, so the historical duality that might serve as a 
theoretical foundation for "Strawman" Theory is now irrevocably and innately melded together into a single unit. ${ }^{88}$ Any human being is a legal person.

Similarly, unilateral claims to reject state authority and withdraw consent were not issues of national legal relevance. This element of "Strawman" Theory is a distorted version of the social contract concept, ${ }^{89}$ where the social contract is between an individual and the state, rather than a community or democratic delegation of authority. ${ }^{90}$

In the past several years, a more sophisticated variation on the Menardian "Strawman" has emerged, but it too has been implicitly rejected by the Supreme Court of Canada. This version, taught by guru "John Spirit" (a pseudonym), claims that international treaties are supraconstitutional authorities in Canada as they are incorporated into the Charter. The Spirit variation on "Strawman" Theory then has the human being, "a human being with full legal capacity," invoke the inherent jurisdiction of a court to enforce clauses of the International Covenant on Civil and Political Rights, the International Covenant on Economic, Social, and Cultural Affairs, and the UN Declaration of Human Rights as binding and superior authorities that restrict Canadian governments and courts, and impose spurious alleged obligations via the Charter.

In the Spirit scheme, a human being may reject their "Strawman" by reference to Article 16 of the International Covenant on Civil and Political Rights: "Everyone shall have the right to recognition everywhere as a person before the law." ${ }^{.93}$ OPCA litigants claim that the "person before the law" status mandated by Article 16 is an individual privilege. They opt out of that, purportedly making the OPCA litigant then immune to Canadian law, government, police, and courts.

As was observed in Pomerleau, ${ }^{94}$ if an individual could renounce their "person before the law" status, the result under traditional English common law would not be a human being who is free from government or legislative control, but instead an individual who is some form of property. Fortunately, this outcome is nothing more than a thought experiment, since rejecting legal person status is impossible under modern Canadian law.

The Spirit "Strawman" has been broadly rejected by Canadian provincial and Federal courts. ${ }^{95}$ The d'Abadie $37507 / 8$ and Royer 37408 leave applications are clearly based on the

\footnotetext{
See note 19.

Reviewed by JW Gough, The Social Contract: A Critical Study of Its Development (Oxford: Clarendon Press, 1936).

Netolitzky, "Rebellion," supra note 7 at 10-11.

Netolitzky, "Hammer," supra note 21 at 1198.

Pomerleau, supra note 12 at para 26.

19 December 1966, 999 UNTS 171, art 16 (entered into force 23 March 1976) [ICCPR].

Pomerleau, supra note 12 at paras 89-95.

Ibid; d'Abadie, supra note 40; Re Gauthier, 2017 ABQB 555, leave to appeal denied, 2018 ABCA 14; Claeys v R, 2013 MBQB 313 [Claeys]; O'Brien v Murchland, 2013 ONSC 4576; $R$ v Barens, 2016 BCCA 389; Bursey v R, 2015 FC 1126, Bursey v R, 2015 FC 1307, aff'd Dove v R, 2016 FCA 231; Holmes $v$ R, 2016 FC 918; Lynch v R, 2017 FCA 248; Fazakas v R, 2018 NBQB 12. Schemes related to the Spirit "Strawman" variant were rejected in Fiander, supra note 17; Doell $v$ R, 2016 FCA 235; Bouchard v R, 2016 FC 983; Banque Royale du Canada c Demers, 2016 QCCQ 9613; R v Freer, 2017 ONCJ 623; White, supra note 40; Autorité des marchés financiers c Nadeau, 2018 QCCS 3069, leave to appeal refused 2018 QCCA 1762; Howard v AG of Canada, 2018 ONSC 785, aff'd 2019 ONCA 351; Walsh v AG of Canada, 2018 ONSC 2251; Brown v Canada (AG), 2019 YKSC 21.
} 
Spirit "Strawman" scheme; however, that complete argument is only discernable in the d'Abadie 37507/8 application, given the cryptic description $(\mathrm{kS}=4)$ in Royer 37408 of how international treaties and the Charter purportedly interact.

Ste-Marie 37452 and Barens 37656 apply Spirit's theories in a similar way, but with a different objective. These applications claim the combined operation of the Charter,${ }^{96}$ the ICCPR, ${ }^{97}$ International Covenant on Economic, Social, and Cultural Affairs, ${ }^{98}$ and Universal Declaration of Human Rights ${ }^{99}$ gives individuals absolute rights to property and to operate motor vehicles.

A second major conclusion flowing from this investigation is that the Supreme Court of Canada has implicitly considered and rejected a broad range of arguments that some kind of rule-based authority trumps Canadian law. The Study Group application denials implicitly reject many commonly encountered alleged supraconstitutional OPCA authorities:

- $\quad$ the King James Bible (Lindsay 34331);

- $\quad$ the Magna Carta (Lindsay 31204, Medd 29414);

- $\quad$ historical English common law (Medd 29414);

- Aboriginal law or authorities (AC 37380, Louison 34570, Miracle 37631); and

- international human rights treaties (ICCPR, International Covenant on Economic, Social, and Cultural Affairs, UN Declaration of Human Rights, and United Nations Declaration on the Rights of Indigenous Peoples) (Ste-Marie 37452, d'Abadie 37507/8, Miracle 37631, Barens 37656).

Last, the Supreme Court of Canada has implicitly considered and rejected that governments operate secret bank accounts related to each person, which may be accessed by exotic means. $^{100}$

\section{B. Canadian Appellate OPCA Litigation}

This article's second objective is to investigate possible differences between trial and appellate OPCA litigation.

\section{LitigATION OBJECTIVES}

While the Study Group leave applications' pseudolegal objectives generally correspond to Canadian OPCA litigation as a whole, Table 1A does reveal a significant difference. paras 531-43. 
Attempts to assert and impose pseudolegal authority on government and institutional actors were almost three times (39.2 percent versus 13.8 percent) more frequent in the Study Group than the larger reported case law Dataset.

Attacks on conventional authority reflect pseudolaw communities' anti-social, conspiratorial political orientation. ${ }^{101}$ The over-representation of pseudolaw attack litigation in the Study Group appears to link OPCA appeals to ideologically oriented, rather than defensive, OPCA objectives.

\section{STUdy GROUP SRL APPLICATIONS}

OPCA trial-level litigation has a well-justified reputation for usually being an amateurish and confusing affair. ${ }^{102}$ Many OPCA litigants, particularly Freemen-on-the-Land, have, at best, a superficial understanding of law and procedure. ${ }^{103}$

Given that, the large majority of SRL Study Group leave applications were surprisingly well-prepared. Most applications clearly set out the litigation background, identified and explained issues, and cited authorities. The SS values for Study Group applications reflect that pattern, with an average score of 3.1. As Figure 2 illustrates, many SRL applications were professional legal documents.

The Study Group leave applications were not simply intended as a delay tactic or as notational placeholder litigation, with the objective of deferring an unfavorable litigation result or inflicting expense. Aside from a limited number of exceptions, such as McElheran 29372 and Hlatky 35408, the Study Group appeals were a serious attempt to have the Supreme Court of Canada consider questions of law.

That said, the Study Group applications exhibit a broad spectrum of content, organization, and reasoning. Thompson 36111 is one extreme: a brief handwritten document that invoked habeas corpus, and cited no authorities, other than two Criminal Code sections. One, section 39 , had previously been repealed in 2012. Nevertheless, Thompson's argument is brief, but clear. To be fair to Thompson, he was at this point likely incarcerated, ${ }^{104}$ and the superficial and unsophisticated concepts in his appeal are standard fare for the Freeman-on-the-Land community. ${ }^{105}$

Unrau, supra note 23 at paras $182-83$.

Meads, supra note 17 at paras 204-205, 251.

Netolitzky, "Hammer," supra note 21 at 1197-98; Netolitzky, "Lawyers," supra note 79 at 448.

See Terry Thompson $v$ The Correctional Service of Canada (Warden, Atlantic Institution), 2015 NBQB 216, aff'd 2016 CanLII 56171 (NBCA), leave to appeal to SCC refused, 37484 (25 May 2017). Thompson in 2017 continued to claim that as a Freeman, he was exempt from criminal sanction, when he was sentenced to 3.5 years incarceration for attacking a fellow prisoner with a "shank" (an improvised knife): $R v$ Thompson, 2017 NBQB 81 at para 15. Justice Walsh's evaluation of Thompson was unfavorable: "To even pretend to consider the potential for the accused's rehabilitation would be a joke" (ibid at para 14).

See Part IV.B.4, below. 
Similarly, Miracle 37631 is an unsophisticated, unsupported statement of alleged pseudolegal principles. It is difficult to criticize Miracle. He was simply repeating the same incoherent arguments advanced by his former counsel, Glenn Bogue, in AC 37380. ${ }^{106}$

The arguments in Williams 33209 and Williams 33211 were substantially drawn from US OPCA sources, and a significant part of the leave application text appears to have been simply “copy pasted" from OPCA sources, a blog website, and older legal texts. ${ }^{107}$ The result is both difficult to understand and provides little basis for a genuine appeal. Williams also engaged in "bizarre" and "exotic" OPCA litigation in the US. ${ }^{108}$

While notorious Detaxer guru David Kevin Lindsay ${ }^{109}$ has been repeatedly declared vexatious $^{110}$ and prohibited from court representation, ${ }^{111}$ the Study Group applications he filed or prepared fall on the opposite end of the spectrum. Many of Lindsay's Study Group applications were legally conventional (Table 2), and address important issues including transcript costs (Lindsay 26150, Lindsay 27181, Lindsay 31204), the criteria that disqualify a layperson agent in criminal proceedings (Dick 29128), the scope of evidence that is relevant to determine vexatious litigant status (Lindsay 32026), and the role of the Attorney General in section 507.1 of the Criminal Code ${ }^{112}$ pre-enquête hearings (Ambrosi 35979). Lindsay has clearly spent a great deal of time attempting to learn legal principles and procedure. For example, he self-published a well-researched, largely accurate, conventional textbook on the Criminal Code private information process, ${ }^{113}$ provided one overlooks Lindsay's extremist political perspectives.

While Lindsay is a legally competent SRL, he is not the only example. Lewry 34898 is well-prepared and argued in relation to the Charter implications of alternative search regimes, though the application fails to address an issue of court jurisdiction, the basis on which it and parallel litigation were rejected at the Federal Courts. ${ }^{114}$ Here, the basic argument was sound, but the SRL OPCA litigant failed to acknowledge a fatal procedural defect. ${ }^{115}$ Watts 38141 advances a variation of this argument, but one argued in the correct trial court forum.

An alternative explanation is Miracle 37631 was prepared by Bogue, since Bogue was suspended on 12 April 2017 (Law Society of Upper Canada v Bogue, 2017 ONLSTH 119), and Miracle filed his appeal on 27 April 2017.

Williams 33209 at 14-18, 23; Williams 33211 at 14-18, 22.

James A Williams Trust v US (29 December 2011), 10-CV-753 (Ct Fed Cl), aff'd (18 December 2013), 2012-5070 (Cir) [Williams]. Williams, identified as a resident of Toronto, attempted to trigger spurious income tax refunds via a 1099-OID form. Williams claimed his "attornatus privatus" status meant he issued judgments in this proceeding, which was described as a "novel system."

Netolitzky, "History," supra note 18 at 620-21.

AG of Manitoba $v$ Lindsay, 2000 MBCA 11; AG of BC $v$ Lindsay, 2007 BCCA 165.

$R v$ Main, 2000 ABQB 56; Hill v Hill, 2008 SKQB 11; Warman v Icke, 2009 CanLII 43943 (Ont Sup Ct) at para 1; Ambrosi, supra note 74; Superior Filter Recycling Inc v R, 2006 FCA 248; $R$ v Lineham, 2000 ABQB 815; Morin c R, 2015 QCCA 2156.

CC, supra note 1 .

CLEAR, The Criminal Charging Procedure (self-published). This book probably dates to 2014, and is an updated and much expanded version of an earlier text, David-Kevin Lindsay, How To Lay Criminal Charges (self-published), published in the early 2000s.

The Lewrys' Federal Court litigation was one of three parallel actions that were rejected on this basis: AG of Canada v Siggelkow, 2012 FCA 123; AG of Canada v Blerot, 2012 FCA 124; AG of Canada v Lewry, 2012 FCA 125.

Douglas Lewry appears to have advanced less conventional arguments in a Federal Court action where he self-identified as a "natural person" in the style of cause, very likely invoking a "Strawman" Theory distinction: Douglas Lewry (Natural Person) v Minister of National Revenue, Regina T-1430-11 (FC) (struck out 23 December 2011). 
Other leave applications see pseudolaw motifs intrude into what was otherwise conventional litigation. Reckless 36356 accurately surveys Canadian authorities where silence in response to partial payments of a debt indicated the creditor agreed the debt was completely satisfied. Then, unexpectedly, the appellant invokes the US Uniform Commercial Code, "to which Canada remains a signatory,"116 despite the fact that model American legislation has no binding authority in any jurisdiction, let alone Canada. ${ }^{117}$ The appellant also, without explanation, identifies banks as "pure fiction[s]" that are incapable of contractual relations. ${ }^{118}$

Similarly, the Drosdovech 33143 appeal is largely a legally comprehensible exercise in statutory interpretation. The appellant cited appropriate authorities and principles, but then introduces an "everything is a contract" argument that is obviously false in law.

Two specific weaknesses were repeatedly encountered in the SRL Study Group leave applications. The first is a failure to identify and respond to unfavorable jurisprudence on the same issue. For example, the argument advanced in Lewry 34898 was considered and rejected in an earlier British Columbia action, ${ }^{119}$ which was certainly known to the Lewry 34898 appellants. The earlier case was the prosecution of the Lewrys' OPCA guru. ${ }^{120}$ Nevertheless, Lewry 34898 does not respond to this contradictory authority. Many leave applications that attempt to argue "Strawman" Theory make no reference to the numerous decisions that have already rejected that concept. ${ }^{121}$ Royer 37408 is a notable exception, where the appellants specifically identify Canada (Minister of National Revenue) $v$. Stanchfield ${ }^{122}$ as an opposing authority, and request that the Supreme Court of Canada reject the reasoning in that decision. ${ }^{123}$

The second commonly observed defect was inaccurate, erroneous, or irrelevant citations to cases and authorities. Several examples of that issue are described above for Dalle Rive 25874, but this phenomenon was common throughout the Study Group leave applications.

Another interesting example is d'Abadie 37507/8, which cites a Manitoba Queen's Bench decision, Claeys, ${ }^{124}$ as an authority for d'Abadie's "waiving my right to be a person at law." 125 Claeys certainly is highly relevant to d'Abadie's argument. In that decision TheresaMarie Katherine Claeys, "a human being," invoking the John Spirit "Strawman" and international treaty scheme, demanded her last ten years of income tax refunded, and half a million dollars in damages. ${ }^{126}$ Unsurprisingly, Claeys' action was struck out. Did d'Abadie

Reckless 36356 at paras 49-50.

Many US jurisdictions have enacted variations on some or all of the model Uniform Commercial Code provisions. See online: <law.cornell.edu/ucc/index.html $>$.

Reckless 36356 at paras $31-32$.

$R v$ Porisky, 2012 BCSC 68; other courts reached the same conclusion in $R v$ Siggelkow, 2014 ABQB 101, and Amell $v$ R, 2013 SKCA 48; however, those decisions post-date the Lewry 34898 leave application.

Netolitzky, "Lawyers," supra note 79 at 441-45.

For example: Lindsay 31465, Lindsay 34331, Dalle Rive 35874, Bloom 37391, d'Abadie 37507/8. 2009 FC 99.

Royer 37408 at para 64.

Supra note 95.

d'Abadie 37507/8 at Part I, para 14(c); see also Part 1, para 17; Part III, para 17.

Supra note 95 at para 3. 
not actually read the Claeys decision, or was his knowledge of law so flawed he did not recognize that this authority worked against him?

d'Abadie also cites $R$. v. Eldorado Nuclear Ltd. ${ }^{127}$ as a basis for why d'Abadie: (1) is immune to criminal legislation "because there [was] no evidence I was acting commercially or engaging the public in anyway," (2) cannot be imprisoned because he does not hold "an office within the federal juristic unit," and (3) is subject only to common law. ${ }^{128}$ The actual subject of Eldorado was the degree to which Crown immunity extends to an agent of the Crown - the opposite scenario than that claimed by d'Abadie.

Some citations by OPCA SRL litigants seem all but random. For example, Henry 34172 describes the activities of several doctors ${ }^{129}$ and then cites Housen $v$. Nikolaisen, ${ }^{130}$ which sets the deferential appellate standard of review for findings of fact. A few paragraphs later, ${ }^{131}$ Henry cites the Criminal Code ${ }^{132}$ which states that court decisions take effect immediately, rather than only when reduced to writing. To the degree it is comprehensible, the Henry 34172 litigation is a medical malpractice action, so this Criminal Code reference makes no sense at all.

This bad citation defect even appears in the usually better-prepared Lindsay leave applications. For example, Lindsay 31465 at paragraph 28 states:

\footnotetext{
Nor are these trivial points, for statutory Provincial Court judges only have jurisdiction over the courtroom itself not the courthouse, and a failure to comply with statutory duties involves a loss of, or failure to obtain jurisdiction, such as the instant case.
}

Lindsay 31465 then cites CBC v. Quebec Police Comm., ${ }^{133}$ where the Supreme Court of Canada found the Commission had no contempt authority since it was not a court, and Doyle v. $R,{ }^{134}$ which concluded that the Criminal Code is a complete code for the purposes of adjourning criminal proceedings. Neither authority mentions "courtrooms" or "courthouses" at all.

If nothing else, this pattern illustrates why lawyers and courts responding to this class of litigation should carefully scrutinize any legal authorities identified by OPCA litigants. Their citation track record is, to be generous, questionable.

\section{FORM DOCUMENTS, OTHERLAW, DOCUMENTARY MAGIC, AND ATtEMPTS TO COMPEL THE SuPREME COURT OF CANADA}

The surprising absence of certain commonplace pseudolaw litigation motifs is further evidence that appellate OPCA activities may be distinct from at-trial conduct. 
Many trial decisions report that OPCA litigants employ pre-prepared form or template documents, ${ }^{135}$ sold as part of pseudolaw commercial products. ${ }^{136}$ No examples of that were identified in the Study Group applications.

Documents filed by OPCA litigants sometimes exhibit unusual but highly stereotypical markings, language, and other atypical motifs. ${ }^{137}$ Sometimes these unusual features have a well-defined pseudolegal meaning, such as how Elio Dalle Rive used letter case to distinguish between himself and his "Strawman." These unique and characteristic documentary motifs have been used to screen and reject OPCA court filings. ${ }^{138}$

Other atypical documentary features are difficult to explain in any conventional or logical sense. The ritual-like character of some OPCA litigation activities ${ }^{139}$ is better understood as "Otherlaw," an attempt to engage in magic, rather than a rational activity. ${ }^{140}$ For example, some pseudolaw documents are blatantly fake imitations of genuine articles. ${ }^{141}$ Presumably, these items are expected to influence the courts by sympathetic magic. ${ }^{142}$

Social science investigators identify "Fantastical Believers" in the OPCA litigant population $^{143}$ and draw parallels to religious cults. ${ }^{144}$

Unexpectedly, the unusual formatting, structure, and ornamentation frequently found in many trial-level OPCA documents ${ }^{145}$ was largely absent from the Study Group.

The most common OPCA documentary motif was the dash-colon name structure ${ }^{146}$ used to indicate the human being half of the "Strawman" duality (10 of 51 applications). Other appellants used titles to identify their human-only status:

- “a flesh and blood living soul man ... a free will, common law man of inherent jurisdiction"; 147

- " "human being Grantee/Grantor/Beneficiary"; 148

See Rogozinsky, supra note 44; Alberta Treasury Branches v Nielson, 2014 ABQB 383; Servus Credit Union Ltd v Parlee, 2015 ABQB 700.

Meads, supra note 17 at para 86.

Surveyed in Meads, ibid at paras 203-41.

Unrau, supra note 23 at para 22; McRoberts, supra note 19 at 661-62.

Meads, supra note 17 at paras 77-80.

Netolitzky, "Magic,” supra note 7; Spencer Dew, “"Moors Know the Law': Sovereign Legal Discourse in Moorish Science Religious Communities and the Hermeneutics of Supersession" (2016) 31:1 JL \& Religion 70 at 87-91; Catherine Wessinger, How the Millennium Comes Violently: From Jonestown to Heaven's Gate (New York: Seven Bridges Press, 2000) at 160; David Griffin, Truth Language: The Pseudolegal Discourse of the Sovereign Citizen Movement (MA Dissertation, Cardiff University School of English, Communication and Philosophy, 2017) [unpublished].

Bossé v Farm Credit Canada, 2014 NBCA 34 at Appendix B [Bossé].

Netolitzky, "Magic," supra note 7 at 1053-56; Griffin, supra note 140.

Perry, Hofmann \& Scrivens, supra note 18 at 35-36.

Stephen A Kent \& Robin D Willey, "Sects, Cults, and the Attack on Jurisprudence" (2013) 14:2 Rutgers JL \& Religion 306.

Meads, supra note 17 at paras 203-41.

Ibid at paras 206-208.

Dalle Rive 35874 at para 4.

Dove 37487 on its front page. 
- "Private Person - All Rights Reserved"; ${ }^{149}$ and

- "The Natural and Sovran-on-the-land, flesh, blood and bone, North America Signatory Aeriokwa tence Kanienkehaika Indian Man."

Bloom also claimed to represent himself, "Constitutional Consultant Amicus Curiea for Applicants," and titled the respondent "Her Majesty The Queen Not In Right of Canada," represented by the "Department of Non Justice." Similarly, in Williams 33209 and Williams 33211, the appellant titled himself "Attornatus Privatus." 151

Few applications exhibited more flamboyant OPCA document ornaments: fingerprints in blood or ink, postage stamps, multicoloured text and signatures, or unorthodox seals and notarial marks, and so on. ${ }^{152}$ Williams 33209 and Williams 33211 were marked at several locations with a seal that appears to read: "James Andrew Williams, Imperial Soul, Jus Naturale." Williams 33211 on its front page also featured a felt marker notation:

Accepted for Value Honour and Consideration UCC 3-501 Exempt from Levy By: James Williams UCC 1308 sovereign ally of Her Majesty queen elizabeth the second. ${ }^{153}$

Dalle Rive 35874 included an unconventional notarial act witnessed by a non-practicing lawyer.

Study Group docket records also do not generally record illusionary "default judgments," $" 154$ or allegedly binding orders that purport to originate from an unorthodox or vigilante court. ${ }^{155}$ Again, the Williams 33209 and Williams 33211 appeals are potential exceptions. Supreme Court dockets indicate Williams filed "Letter Rogatory," "Praecipe for Writ of Fieri Facias," "Praecipe for Writ of Detinue Sur Trover," and "Praecipe for Writ of Replevin" documents in these actions. ${ }^{156}$ These are clearly inappropriate for a Supreme Court of Canada appeal. The first document requests assistance from a foreign court, and the three "Praecipes" relate to property remedies.

In earlier proceedings, the Bossés' claimed that a notary operated as a judge and issued a binding decision. ${ }^{157}$ That claim was not pursued at the Supreme Court of Canada.

149 d'Abadie $37507 / 8$ on its front page.

$150 \quad$ Bloom 37391 on its front page.

151 Williams, supra note 108.

152 Griffin, supra note 140, illustrates many examples; see also Netolitzky, "Magic," supra note 7 at 1054-69.

153 Williams 33211; this appears to be a variation on cryptic notations involved in "A4V" schemes and OPCA mantra replies mentioned in Meads, supra note 17 at paras 217-19, 249.

154 For example: Re Boisjoli, 2015 ABQB 629 at paras 23, 49-57; Rothweiler v Payette, 2018 ABQB 134 at paras 18-29; Pomerleau, supra note 12 at para 137; Netolitzky, "Magic," supra note 7 at 1062.

155 See Chalupnicek $v$ CAS Ottawa, 2016 ONSC 2787 at para 10; Rothweiler \#4, supra note 66 at para 66; Netolitzky, "Magic," ibid at 1053-56; Knutson, supra note 54 at paras 72-79.

156 Williams 33209: 10 July 2009, 7 August 2009, online: <scc-csc.ca/case-dossier/info/dock-regieng.aspx?cas=33209>; Williams 33211: 10 July 2009, 7 August 2009, online: $<$ scc-csc.ca/case-dossier/ info/dock-regi-eng.aspx? cas $=33211>$.

157 Bossé, supra note 141 at Appendix B; Donald J Netolitzky, "Humdrum Becomes a Headache: Lawyers Notarizing Organized Pseudolegal Commercial Argument Documents"(2019) 49:3 Adv Q 279 reviews this motif. 
The absence of these commonplace trial-level OPCA motifs from the Study Group applications is unexpected, and has no obvious explanation. One possibility is the Supreme Court of Canada Registrar refuses to accept documents with certain unorthodox features. A second alternative is the standardized forms ${ }^{158}$ made available to leave applicants help structure and focus the submissions of these highly unusual SRLs.

A third explanation is a form of self-selection. Recourse to 'litigation magic' may be more common among less sophisticated OPCA litigants, or OPCA litigants who hold unusual personal and conspiratorial beliefs. ${ }^{159}$ These individuals may lack the aptitude to navigate their dispute through several tiers of courts to the Supreme Court of Canada. Another possible form of self-selection is the degree of commitment to pseudolaw. Prior investigation indicated some populations who advance "magical" pseudolaw are "mercenaries" who do not believe in pseudolaw, but instead adopt these strategies for an anticipated benefit. ${ }^{160}$ Perhaps only true believers seek out review at the Supreme Court of Canada.

The net result is, however, clear. Most OPCA Study Group leave applications involve highly unorthodox concepts, but these ideas and arguments were usually presented in a serious, careful, and conventional manner. The large majority of the Study Group appellants were at the Supreme Court of Canada to argue their ideas, rather than attempt to impose some kind of extraordinary unorthodox judicial or magical authority.

\section{DETAXER VS FREEMAN-ON-THE-LAND APPELLATE ACTIVITIES}

Another question is to what degree the Study Group applications parallel the different and distinct trial-level litigation patterns of Canada's two main branches of pseudolaw.

Circa 2000, the US-sourced Pseudolaw Memeplex was adopted by two sizeable ${ }^{161}$ but quite different communities: the Detaxers and the Freemen-on-the-Land. The majority of leave applications in the Study Group show affiliations to these two groups (PreDetaxers/Detaxers: N=30; Freemen-on-the-Land: $\mathrm{N}=12$ ).

While both groups use practically identical pseudolaw concepts, the social objectives of these two "OPCA movements"162 were very different. Detaxers claimed they had no obligation to pay income tax. ${ }^{163}$ Freemen instead rejected all state authority, except where they consent to it, ${ }^{164}$ typically to obtain government benefits as "Freeloaders-on-the-Land." 165

Supreme Court of Canada, "Forms" (26 May 2017), online: <scc-csc.ca/unrep-nonrep/app-dem/formsformulaires-eng.aspx>.

Netolitzky, "Magic," supra note 7 at 1080-84; Perry, Hofmann \& Scrivens, supra note 18 at 35-37. Netolitzky, "Magic," ibid at 1079-80.

A number of other OPCA movements are known in Canada but have comparatively few adherents, see Netolitzky, "History," supra note 18 at 627-32; Meads, supra note 17 at paras 176-96. The only Study Group applications that obviously originate from these minority pseudolaw populations are Henry 33994 and Henry 34172 (Moorish Law), and Bossé 36026 (Sovereign Citizen/Quebec hybrid A4V variant). Meads, ibid at paras $168-75$.

Netolitzky, "History," supra note 18 at 616-24.

Ibid at 624-27.

Ibid at 639 . 
The Detaxers combined US ideas with Canada-specific pseudolaw previously developed by a small Pre-Detaxer community. ${ }^{166}$ The founder of the Freeman movement, Robert Arthur Menard, subsequently crudely and superficially copied and adapted Detaxer concepts to purportedly nullify all state authority. Despite his prominence in pseudolegal circles, Menard's grasp of law is best described as unsophisticated, ${ }^{167}$ and grossly inferior to the Detaxer gurus, such as Lindsay.

The Freemen-on-the-Land remain active in Canada, though their community is reduced and balkanized between multiple competing guru influences. ${ }^{168}$ The Detaxers went extinct after the final Detaxer schemes, the Paradigm Education Group and Fiscal Arbitrators, collapsed around 2009-2010. ${ }^{169}$ There is little evidence of any successor Detaxer leaders or schemes. ${ }^{170}$

The Detaxer movement's trial-level litigation focus continued on appeal. Detaxer Study Group application pseudolaw strategies were almost exclusively directed to eliminating income tax obligations or to "get out of jail free" (Table 1B). Common Detaxer arguments were the ITA has no legal force, is ultra vires, or does not apply to natural persons. As illustrated in Table 4, many of these arguments were implicitly rejected by the Supreme Court of Canada when it refused to grant leave to a general question that was clearly expressed and had national significance: the operation and legal validity of federal income tax. The Study Group applications are therefore a strong basis to conclude that arguments advanced by the Detaxer OPCA movement and its Pre-Detaxer precursors will not meet with future success.

In contrast, but consistent with their anti-state and anti-authority orientation, three quarters of the Freeman Study Group leave applications applied their pseudolaw to attack government and institutional actors (Table 1B). Freemen often engage in criminal misconduct, ${ }^{171}$ and, unsurprisingly, many Freeman Study Group applicants sought to "get out of jail free" (Table 1B).

Figure 3 illustrates these populations' knowledge of law and capacity to organize facts and legal argument were markedly different. The average SS for SRL Pre-Detaxer and Detaxer leave applications is $3.48(\mathrm{~N}=30)$, while SRL Freemen averaged a dismal SS of $2(\mathrm{~N}=12)$.

This parallels previous evaluations of the different intellectual styles of these OPCA movements and their guru leadership. ${ }^{172}$ So do the kinds of litigation arguments found in the Study Group applications. None of the legally conventional applications in Table 2 were filed

$166 \quad$ Ibid at $613-16$.

167 Netolitzky, "Pathogen," supra note 19 at 9-10; Netolitzky, "Hammer," supra note 21 at 1194-96; Netolitzky, "Magic," supra note 7 at 1073-75.

168 Netolitzky, "History," supra note 18 at 639; Perry, Hofmann \& Scrivens, supra note 18 at 16-18, 44-45.

169 Netolitzky, "Lawyers," supra note 79 at 430-34, 441-48.

170 One exception is Paradigm Education Group Detaxer Eric Ho, who operates a website (online: $<$ canadaincometaxislegal.is $>$ ) where he promotes "Apu's Theory," a variant of Paradigm Education Group theories where "Social Insurance Number" and "social insurance number" allegedly have different legal meanings. Reported case law provides little evidence of taxpayers using Apu's Theory.

172 Netolitzky, "Lawyers," supra note 79 at 448. 
by a Freeman; all Table 2 applications were by OPCA litigants associated with the PreDetaxer and Detaxer movements.

Most OPCA movements are organized around leader/teacher figures, or "OPCA gurus."173 The Study Group includes leave applications from three OPCA gurus: David Kevin Lindsay, Lawrence Watts, and Wallace (Wally) Raymond Maxwell Dove. Their Supreme Court of Canada activities also reflect the Detaxer/Freeman divide.

As previously indicated, Lindsay was a very prominent Detaxer guru, and filed a number of relatively professional and well-argued leave applications.

Lawrence Watts filed an interesting leave application in 2018 attacking his conviction for fraud. ${ }^{174}$ Watts was a kingpin behind the Fiscal Arbitrators OPCA scam, ${ }^{175}$ an unsophisticated Detaxer scheme where income was purportedly offset by fictitious losses: human beings claimed operating their "Strawmen" as business expenses. Watts' superficially impressive leave application alleges section 380(1) of the Criminal Code (fraud) is unconstitutional, but, in substance, that was actually an attack on the Klundert Trilogy ${ }^{176}$ rule that incorrect tax theories do not provide a mistake of law defence.

The third guru, Dove, was at one point a part of the Detaxer (and possibly even PreDetaxer) communities. ${ }^{177}$ By the time of his 2016 Dove 37487 leave application, Dove had graduated to become a full-fledged guru and applied Freeman concepts. In addition to his personal tax evasion activities, Dove misused his status as a Certified General Accountant (CGA), to the direct harm of his clients. In 2003, Dove was expelled from the CGA Professional Association and fined after a discipline committee found he had engaged in incompetent and unprofessional conduct. Dove applied unlawful Detaxer strategies in the official taxation affairs of a business client. The Accountant's Professional Conduct Tribunal considered, and rejected, all OPCA arguments Dove advanced in his own defence. ${ }^{178}$

Despite his dodgy history, Dove is the dominant personality in the Human Rights Defenders League In Canada (HRDLIC) ${ }^{179}$ the publisher of an OPCA text, The Solution To ALL our Problems. ${ }^{180}$ Dove's HRDLIC ideas adapt the Freeman-style John Spirit argument that international treaties have supraconstitutional status via the Charter to not only deny state authority, but also demand damages of $\$ 100,000,000.00$, and a kind of treaty-mediated social welfare scheme. ${ }^{181}$

Meads, supra note 17 at paras $85-158$.

Watts received a six-year sentence after a jury conviction: $R v$ Watts, 2016 ONSC 4843, aff'd 2018 ONCA 148, leave to appeal to SCC refused, 38141 (27 September 2018). In a bizarre twist, Watts recently appeared as a witness for his former clients, providing evidence that the "Strawman" business expense claim is legally correct: Kim v R, 2017 TCC 246 at paras 22-26. Unsurprisingly, Watt's testimony was rejected as "inherently unreliable and of no probative value whatsoever" (ibid at para 53). Netolitzky, "Lawyers," supra note 79 at 430-34.

Ibid at 455-57.

$R v$ Dove, 2004 CanLII 31861 (Ont Sup Ct J); Rv Maleki, 2006 ONCJ 401.

Re Dove (2003) (CGA Association of Ontario Professional Conduct Tribunal), online: <media.cpa ontario.ca/stewardship-of-the-profession/pdfs/1011page21042.pdf>.

See Human Rights Defenders League in Canada, online: [web.archive.org/web/20181231202003/ http://humanrightsdefendersleague.ca/].

The Human Rights Defenders League In Canada, The Solution To ALL Our Problems (self-published, revised 2012). This text has circulated in a number of electronic and hard-copy versions. Bursey v Canada, 2015 FC 1307. 
Unexpectedly, the Dove 37487 leave application is nearly incoherent $(\mathrm{SS}=2, \mathrm{kS}=4)$, and only hints at arguments that were more fully developed in the lower court proceedings and Dove's other writing. One possible explanation is Dove 37487 was a "pared-down" appeal that attempted to evade criticism of OPCA concepts and Meads, which was cited against Dove in the lower court proceedings.

While the diverging litigation style and different dispute subject foci that distinguish the Pre-Detaxer/Detaxer and Freeman communities are obvious in the Study Group leave applications, there may be a change underway in the Freeman approach to legal argument. Pseudolaw taught by early gurus such as Menard and Dean Clifford ${ }^{182}$ had little to do with actual Canadian law, and instead involved little more than empty mantras. However, the new "Strawman" Theory variant taught by John Spirit is grounded on specific court decision passages largely cited from Supreme Court jurisprudence. ${ }^{183}$ Spirit's theories have clearly been met with broad interest, ${ }^{184}$ and may have triggered a shift towards more conventionally argued Freeman OPCA litigation. The appeals that most closely implemented Spirit's theories (Royer 37408, Ste-Marie 37452, d'Abadie 37507/8, Barens 37656) represent the high SS end of the Freeman Study Group leave applications.

Thus, the Freeman-on-the-Land movement is perhaps now growing past its progenitors. Whether this new approach to pseudolaw by the remnant Freeman community will result in a new set of theories will be interesting to observe.

\section{LAWYER PARTICIPATION IN STUDY GROUP LEAVE APPLICATIONS}

A recent article investigated Canadian lawyer representation of persons who engaged in OPCA activities. ${ }^{185}$ Source data was drawn from reported court decisions that involve OPCA elements and concepts. The current study provides the opportunity to expand on Netolitzky, "Lawyers," and investigate whether patterns identified in that study are also reflected in the Study Group appeals.

Interestingly, there are many similarities between Netolitzky, "Lawyers" and the Study Group lawyers. Lawyers prepared 17.7 percent $(n=9)$ of Study Group leave applications, almost exactly the same proportion of lawyer representation reported in Netolitzky, "Lawyers." "186

Netolitzky, "Lawyers" identified three broad categories of lawyer activity: "legitimate representation," where lawyers advanced conventional arguments on behalf of their clients, "Grey Zone" activities where the status of pseudolaw was unclear, and "rogue" representation, where lawyers abandoned conventional legal orthodoxy and adopted and 
advanced pseudolaw. This pattern is also present in the Study Group applications, but with an interesting variation: conventional but problematic lawyer representation.

a. Conventional and Competent Representation

- Douglas Christie, Christopher Maddock

Optometrist Jack Klundert's decades-long dispute with the CRA over Klundert's obligation at law to pay income tax led to five leave applications. In the first three appeals Klundert was represented by lawyer Douglas Christie. While Christie had previously been the subject of harsh criticism by Benchers of the Law Societies of British Columbia and Ontario for unprofessional conduct, ${ }^{187}$ and submitted dubious OPCA arguments in other cases, ${ }^{188}$ his representation of Klundert at the Supreme Court of Canada was largely what one would expect from competent counsel.

Christie was then replaced by British Columbia lawyer Christopher Maddock after Christie's death in 2013. The final two Klundert Supreme Court leave applications (Klundert 35996, Klundert 35997) identify the appellant as "Jack Klundert (Self-Represented)." However, the primary author of these applications was very plausibly Maddock. He was appointed as a British Columbia Provincial Court Judicial Judge shortly after these two leave applications were submitted. ${ }^{189}$

Klundert originally subscribed to an OPCA theory propagated by 1990 s Pre-Detaxer guru Murray Gauvreau ${ }^{190}$ that the British North America Act, $1867^{191}$ division of authority does not permit the federal government to engage in direct taxation. ${ }^{192}$ None of Klundert's Supreme Court appeals actually claimed OPCA arguments were correct. Instead, the central issue was the legal implications of Klundert's belief in those theories, and his subsequent failure to pay income tax.

While Klundert's trials did include legally questionable "Grey Zone” OPCA arguments, ${ }^{193}$ the Christie and putative Maddock appeal applications are entirely conventional, well-drafted documents (SS 4-5).

Christie, Re (22 February 1993), Ont LST. Indeed, Discipline Chair Harvey Strosberg found that Christie had "crossed the line separating counsel from client: and had made common cause with a small, lunatic, anti-Semitic fringe element in our society," (Christie (1993), 12 Lawyers Weekly 1243 [emphasis omitted]). Netolitzky, "Lawyers," supra note 79 at 452-59.

The applications were submitted on 6 August 2014. A tweet from the British Columbia Provincial Court on 4 January 2015 links to a document that refers to Christopher Maddock being sworn in as a Judicial Judge "recently": BC Provincial Court, "BC Lawyers Carmella Osborn \& Christopher Maddock sworn in as Judicial Justices" (4 January 2015 at 21:27), online: <twitter.com/bcprovcourt/status/55195826 $4754106371>$. 
b. Conventional but Questionable Representation

- William Fuhgeh, Bernard Stephaniuk

Other lawyers' participation in the Study Group leave applications is more questionable. Here, the lawyers did not argue pseudolaw, but their applications were problematic in other ways.

The Bossé 36026 application prepared by lawyer William Fuhgeh received a SS of 3 due to a range of defects. Costs were awarded against the appellants by the Supreme Court of Canada. The leave application is all but irrelevant to the issues argued before the New Brunswick Court of Appeal. ${ }^{194}$ In brief, the Bossés and their company had purchased a number of wood lots financed by Farm Credit Canada. When Farm Credit Canada sought to enforce those debts, the appellants responded with an "A4V" money-for-nothing OPCA strategy ${ }^{195}$ where the Bossés claimed they had satisfied all debts with "Private Registered Setoff Bonds" drawn from secret bank accounts operated by the US Treasury. The Bossés also filed a Three/Five Letters ${ }^{196}$ "Notice of Administrative Judgment," where a Quebec Notary, Guy-Paul Gauthier, purported to act as a judge and unilaterally terminated the debt collection process in the Bossés' favour. Justice Richards concluded these OPCA strategies were frivolous, without merit, defied logic, and "the Bossés knew this."197

Fuhgeh's leave application almost entirely evades what the Bossés had actually done, only indirectly mentions the Private Registered Setoff Bonds as (purported) bills of exchange, and implies these OPCA documents should have been enforceable as payments. ${ }^{198}$ However, the Supreme Court of Canada case summary clearly indicates the Court did not succumb to that subterfuge.

Fuhgeh instead advanced peculiar and apparently irrelevant arguments, including:

- Allegations Farm Credit Canada had "concealed evidence evincing ... possession and control of both original Bills of exchange," which in reality were obviously worthless. $^{199}$

- $\quad$ Bald allegations of Charter sections 7, 8, and 15(1) breaches, purportedly flowing from a trial judge who "unreasonably and continuously gave orientation to the [Bossés'] pleadings, giving rise to a reasonable apprehension of bias." ${ }^{200}$ This claim offends the requirement that Charter breach allegations plead details. ${ }^{201}$ Beyond that, how the conduct of a trial hearing could breach the Bossés' section 8 Charter right "to be secure against unreasonable search or seizure" 202 is very difficult to imagine. 
- $\quad$ Approaches to evidence under the Civil Code of Québec ${ }^{203}$ are somehow relevant to litigation conducted in the New Brunswick courts. ${ }^{204}$

- The New Brunswick Court of Appeal erred in dismissing claims the "Property Act" (which is not defined) is "ultra vires from the Bench without calling on either counsel for the respondent or for the Attorney General of New Brunswick to respond." ${ }^{205}$ The Court of Appeal decision reveals the basis for this application was that the Bossés had sent the Canadian and New Brunswick Attorney Generals a "Notice of Demand," and argued failure to respond to that document proved the "Property Act of New Brunswick" was ultra vires. ${ }^{206}$ The "Notice of Demand" included many questions of a dubious OPCA character, for example:

\begin{abstract}
Please provide any and all documents with evidence in support that NEW BRUNSWICK, (United States Securities Exchange Commission under CIK\#: $\mathbf{0 0 0 0 8 6 2 4 0 6}$ is not a fictitious entity and does not operate exclusively under color of law and that the GOVERNMENT OF NEW BRUNSWICK is not a corporate governance of the CORPORATION OF NEW BRUNSWICK and its citizens. ${ }^{207}$
\end{abstract}

- Bald allegations that the appeal decision incorrectly applied the test for summary judgment. Fuhgeh fails to identify any specific defects in the appeal decision. ${ }^{208}$

The Bossé 36026 leave application is strikingly inferior to many SRL leave applications in the Study Group. This application's attempts to skirt the fundamentally pseudolaw-based character of the Bossés' litigation did not benefit Fuhgeh's clients.

Fuhgeh is currently facing professional regulatory proceedings for filing a false affidavit, ill-considered or uninformed allegations of collusion and bias by government lawyers and tribunal officials, incompetent practice, conflict of interest, and intimidation and harassment of the mother of his child. ${ }^{209}$

The Louison 34570 leave application is also questionable. At trial, the plaintiff claimed a novel form of property, "Indigenous Title," which is purportedly superior to Crown interests and those of an Indian Band. ${ }^{210}$ The action was struck out as "Indigenous Title" was expressed as a personal claim, while Aboriginal rights are only communal in nature. ${ }^{211}$ The Saskatchewan Court of Appeal affirmed the trial result in toto. ${ }^{212}$

\title{
203 CCQ
}

204 Bossé 36026 at paras 22-25.

$205 \quad$ Ibid at para 26.

206 Bossé, supra note 141 at paras 24-25, Appendix A.

207 Bossé, ibid at Appendix A, question 18.

208 Bossé 36026 at paras 27-29.

Law Society of Upper Canada v Fuhgeh, 17H-102 (Ontario Law Society Tribunal), Amended Notice of Application - Conduct (1 August 2017); see also Law Society of Ontario v Fuhgeh, 2018 ONLSTH 79; Law Society of Ontario v Fuhgeh, 2018 ONLSTH 119.

210 Louison $v$ Ochapowace Indian Band \#71, 2011 SKQB 87 at paras 5-6.

$211 \quad$ Ibid at paras 8-9.

212 Louison v Ochapowace Indian Band \#71, 2011 SKCA 119. 
Throughout this litigation, Louison was represented by lawyer Bernard Stephaniuk, who also filed the Louison 34570 leave application. Louison 34570 argues that striking out the statement of claim was premature, as amendments could have cured the action's deficiencies. The leave application makes no suggestions of what those amendments might be, does not attempt to substantiate the "Indigenous Title" concept, and does not provide any explanation for why the communal interest rule was incorrect.

After the Supreme Court of Canada refused leave, Stephaniuk then filed an action in Federal Court that was dismissed as a collateral attack on the Saskatchewan litigation, which led to a $\$ 5,000.00$ cost award against Louison. ${ }^{213}$

\section{c. Rogue Lawyers - Glenn Bogue, Michael Swinwood}

The other two lawyers identified in the Study Group, Glenn Bogue (AC 37380) ${ }^{214}$ and Michael Swinwood (Medd 29414), actively and explicitly argued known and rejected OPCA concepts. Lawyers who engage in this form of abusive litigation are "rogue" lawyers, a particularly problematic form of lawyer misconduct. ${ }^{215}$

Netolitzky, "Lawyers" surveyed some of Bogue's OPCA activities. ${ }^{216}$ In brief, between February 2016 and April 2017, when Bogue was suspended on an interim basis, Bogue argued a diverse array of OPCA arguments in at least six disputes ${ }^{217}$ and at multiple levels of court. Bogue appears to be ignoring his suspension, and has appeared or is involved in additional lawsuits in British Columbia and Ontario. ${ }^{218}$

Louison v Ochapowace First Nation, 2015 FC 68, costs awarded 2015 FC 195.

Bogue represented Andrew Miracle before the Ontario Court of Appeal, but is not named in the subsequent Miracle 37631 leave application. Miracle 37631 and AC 37380 exhibit parallel pseudolegal arguments.

Unrau, supra note 23 at para 42.

Netolitzky, "Lawyers," supra note 79 at 472-82. Children's Aid Society of Ottawa v AC, 2016 ONSC 3111 at para 43, reported Bogue filed a habeas corpus application at the Supreme Court of Canada. No corresponding Supreme Court of Canada file was located.

While Netolitzky, "Lawyers," ibid at 472-82, identifies four OPCA disputes conducted by Bogue, the AC 37380 application reveals that in R v Nielsen, 2016 ONCA 635, Bogue argued that a criminal accused should be granted habeas corpus because she was of Jamaican-Danish descent, Métis, and therefore "not subject to Crown Jurisdiction" (AC 37380 at para 47). This OPCA argument is not apparent from the reported decision. Law Society of Ontario v Bogue, 2019 ONLSTH 53 at paras 31-33 [Bogue \#10], indicates in a further lawsuit that after leave was denied by the Supreme Court of Canada (Arcari v Dawson, 2016 ONCA 715, leave to appeal to SCC refused, 37326 (2 March 2017)), Bogue claimed he was appealing that result to the "Kinakwii ASMIN Tribunal."

Grand Chief White Buffalo Eagle v R (23 July 2019), Victoria 1091:83428-1 (BCSC); Baldwin (Grand Chief Buffalo Eagle) $v$ Ontario (AG), 2019 ONSC 2238. Bogue is also plausibly responsible for the litigation reported in Cardin c R, 2019 QCCA 1217; Cardin c R, 2019 QCCA 1354; Cardin c R, 2020 QCCA 98; Anonyme - 191084, 2019 QCCSJ 1047. 
In summary, the OPCA concepts advanced by Bogue in AC 37380 were:

- Aboriginal people (including those of African descent who self-identify as "Moors") $)^{219}$ are only subject to a separate legal system in equity administered by an aboriginal Métis decision-maker.

- $\quad$ The 1613 Two Row Wampum Treaty has supraconstitutional status and permits radical revision of Aboriginal status and rights.

- The “Aboriginal Law of Ma'at" and Métis matrilineal authority from Egypt (Ma'at is an ancient Egyptian goddess) has supraconstitutional status.

A sample passage illustrates the highly unusual and unorthodox terminology and concepts in Bogue's arguments:

Because the Metis Clan Grandmothers trace their land ownership via the female mitochondria trail back through Egypt to Sumer, she has the historic right to have jurisdiction over her children.

The Law of Ma' at is the earliest known version of Natural Justice or the Law of Equity. The Sovereign NonStatus Aboriginals and Metis still have a right to that ancient law via S. 35, since the SCC held in Delgamuukw that S. 35 enshrines their existing rights, but does not define them. One of those rights is to trace back to Natural Justice and the Maxims of Equity that existed prior to the 1881 'merger' of Law and Equity. $^{220}$

Bogue sought leave to appeal two Ontario Court of Appeal decisions, costs of $\$ 500,000.00$, and argued that five additional actions conducted by Bogue also be joined and heard together with the AC 37380 application since "all have Sovereign Jurisdiction of the Metis Nation as their main issue."221

The Law Society Tribunal has concluded Bogue lacks capacity to meet his obligations as a lawyer due to mental illness. ${ }^{222} \mathrm{He}$ had been ordered to undergo psychiatric examination. ${ }^{223}$ Bogue, "a.k.a. Spirit Warrior," has repeatedly demanded panel members recuse themselves, and denied the Law Society Tribunal has jurisdiction over him. ${ }^{224}$ At a 7-8 January 2019 hearing, Bogue summoned officers of the Ottawa Police Service, presumably to arrest the Tribunal panel. ${ }^{225}$ The Law Society of Ontario's slow and apparently ineffectual control of Bogue, an abusive OPCA litigation representative, is troubling.

Bogue says these "Black-skinned Aboriginal Peoples pre-date the arrival of the Crown and are not subject to its jurisdiction, but to their own Judicature": AC 37380 at para 47. This is a Moorish concept that African populations were the original colonists of the Americas: Spencer Dew, "Washitaw de Dugdahmoundyah: Counterfactual Religious Readings of the Law" (2015) 19:2 Nova Religio: J Alternative \& Emergent Religions 65; George F Parker, "Sovereign Citizens and Competency to Stand Trial" (2018) 46:2 J American Academy Psychiatry \& L 167 at 167. AC 37380 at paras $37-38$.

$221 \quad$ Ibid at paras 56-58.

222 Law Society of Ontario v Bogue, 2019 ONLSTH 107 [Bogue \#12].

223 Law Society of Ontario $v$ Bogue, 2019 ONLSTH 52 at paras 67, 86-104.

224 Law Society of Upper Canada $v$ Bogue, 2018 ONLSTH 46; Law Society of Ontario v Bogue, 2018 ONLSTH 135; Law Society of Ontario v Bogue, 2019 ONLSTH 18; Bogue \#12, supra note 222. 
The second rogue lawyer scenario identified in the Study Group is Medd 29414. The authorship of this application is unclear. While Ontario lawyer Michael Swinwood is named as the solicitor for Detaxer James Bradford Medd, the application itself is written from Medd's perspective, is signed by Medd, and states: "Applicant then appealed to the Ontario Court of Appeal, and was informed by his attorney that he was withdrawing from the appeal process." $" 226$

The Supreme Court of Canada leave application argues Medd was immune from paying income tax and had been wrongfully convicted of failing to file income tax returns from $1995-1997 .{ }^{227}$ Medd 29414 largely focuses on a claim that the ITA is ultra vires of the federal government because:

1. the BNA Act, sections $91,92^{228}$ division of power exclusively grants provinces the right to engage in direct taxation; and

2. provinces cannot delegate that authority to the federal government.

This appeal also claimed the Canadian Bill of Rights ${ }^{229}$ had constitutional status, advanced an amorphous argument that the federal government had no authority to collect income tax due to international treaty prohibitions on genocide, and had conspiratorial banking allegations that reflect US Sovereign Citizen concepts that were a precursor to "Strawman" Theory. ${ }^{230}$

Swinwood's role at the Supreme Court of Canada may have been limited, but he was directly implicated in lower court OPCA proceedings. Contemporaneous Detaxer communications indicate Swinwood was fully involved in Medd's litigation and that of another Detaxer, "Tom-Joseph: Kennedy."231 The Medd 29414 application is consistent with arguments advanced by Swinwood personally at an Ontario Superior Court of Justice appeal, including:

1. the BNA Act, sections 91, 92 direct taxation argument;

2. genocide against First Nations people makes the ITA "void ab initio";

3. the ITA offends the Canadian Bill of Rights guarantee of property;

4. ITA offences are cruel and unusual punishment; and

Medd 29414 at para 6 .

ITA, supra note 9 , s 238(1).

Supra note 191.

SC 1960 , c 44.

Koniak, supra note 26.

Also known as "Tommy UsuryFree Kennedy": Netolitzky, "History," supra note 18 at 621 . See also

Rose Anne Kulmala, "Medd Meets Goliath," online: Internet Archive <web.archive.org/web/2000

1215191500/http://cyberclass.net/medd.htm>; "Expenses (Incurred \& Projected) for Tom-Joseph:

Kennedy's CCRA Challenge,” online: [web.archive.org/web/20010712231208/http://www.cyberclass. net:80/ccraexpenses.htm]. 
5. "the scheme of the Income Tax Act of Canada is designed to force an assumpsit contract on an individual, contrary to the Statute of Frauds 1670 and contrary to the Canadian Bill of Rights and the Charter of Rights." 232

The division of powers argument had already been repeatedly and consistently rejected by Canadian trial and appeal courts, ${ }^{233}$ was denied leave by the Supreme Court of Canada, ${ }^{234}$ and runs contrary to a 1924 binding Privy Council authority that concluded the provincial direct taxation authority did not affect the federal jurisdiction to impose an income tax..$^{235}$

Swinwood's "Notice of Appeal" explicitly relies on a self-published book by Pre-Detaxer guru Robert Marquis, ${ }^{236}$ which claims that the 1950 Supreme Court of Canada Attorney General of Nova Scotia v. Attorney General of Canada ${ }^{237}$ decision means the ITA is unconstitutional. That is not an accurate interpretation of the decision.

The purported constitutional status of the Canadian Bill of Rights was previously rejected by the Supreme Court. ${ }^{238}$ The Swinwood/Medd "assumpsit contract" argument is a facet of the Pseudolaw Memeplex "everything is a contract" motif.

The 2003 Medd 29414 Supreme Court of Canada leave application was the last identified example of Swinwood potentially engaged in pseudolegal litigation. The Law Society of Ontario directory indicates Swinwood remains a practicing lawyer, employed by Elders Without Borders, ${ }^{239}$ " a non-profit organization dedicated to championing the sovereignty and rights of indigenous people worldwide, while embracing the wisdom of their culture and spiritual traditions." ${ }^{240}$ Swinwood's post-Detaxer litigation activities often involve Aboriginal communities and issues, such as an unsuccessful 2016 injunction application to block the

See "Medd Appeal Book," online: [web.archive.org/web/20010622201044/http://www.cyberclass.net: 80/meddappealbook.htm].

233 Winterhaven Stables Ltd v Canada (AG), 1988 ABCA 334, leave to appeal to SCC refused, $21262(13$ April 1989); Gullison v Canada, [1992] TCJ No 157 (QL), aff'd [1993] FCJ No 489 (QL) (FCA); Mueller v Canada, [1993] FCJ No 111 (QL) (TD); Rosen v Canada, [1994] TCJ No 810 (QL), aff'd (5 September 1995), Toronto A-558-94 (FCA), leave to appeal to SCC refused, 24965 (6 June 1996); Sarraf v Canada (MNR), [1994] FCJ No 1036 (QL) (TD); Goodwin v Canada (MNR) (1971), 71 DTC 67 Tax Appeal Board; $R$ v Gauvreau (16 June 1995), Grande Prairie 9404-0009S20101 (Alta QB); Charbonneau v Canada (MNR) (1995), 96 DTC 6024 (FCTD); St-Laurent v Canada, [1995] TCJ No 809 (QL); Kasvand v Canada (MNR), [1995] FCJ No 1287 (QL) (FCA); Hoffman v Canada, [1996] FCJ No 699 (QL) (TD); Pilon v Canada, [1996] TCJ No 792 (QL); $R$ v Strang, [1998] 1 WWR 393 (Alta QB); Guillemette v Canada, [1997] 97 DTC 1347 (TCC); Landon v Canada, 1997 CanLII 202 (TCC); $R v$ Josey, [1998] NSJ No 436 (QL) (Prov Ct); Guillemette v Canada, [1998] TCJ No 164 (QL), aff'd [1999] FCJ No 637 (QL) (FCA), leave to appeal to SCC refused, 27280 (16 December 1999); Freeman $v$ Canada, [2001] TCJ No $349(\mathrm{QL})$. Rosen 24965

235 Caron $v R$, [1924] 4 DLR 105 (UK PC) at 108-109: "Upon any view there is nothing in s. 92 to take away the power to impose any taxation for Dominion purposes which is prima facie given by s. 91(3). It is not therefore ultra vires on the part of the Parliament of Canada to impose a Dominion Income Tax for Dominion purposes."

Robert A Marquis, Fraud, Deception, Manipulation: The Parliament of Canada Has Deceived the Canadian People Since 1917 by Imposing Direct Taxation on Incomes and Why This Tax is Illegal (selfpublished, 1999).

[1951] SCR 31.

AG of Canada v Lavell (1973), [1974] SCR 1349.

Law Society of Ontario, "Lawyer and Paralegal Directory" (2020), under Law Society number 14587R, online: <lso.ca/public-resources/finding-a-lawyer-or-paralegal/lawyer-and-paralegal-directory> .

See Elders Without Borders, "Home" (2014), online: [web.archive.org/web/20150812112918/http:// elderswithoutborders.org/ index.html]. 
Cleveland Indians baseball team from displaying their "Chief Wahoo" logo while playing in Toronto. ${ }^{241}$

\section{6. $\quad$ Effect and Influence of Meads v. Meads}

Canadian court decisions consistently reject OPCA concepts as pseudolaw and false; however, the manner and form of that rejection underwent a sea change in 2012 with the release of Meads by the Alberta Court of Queen's Bench, and the subsequent broad adoption of that decision as a key anti-pseudolaw authority. ${ }^{242}$

The OPCA community ineffectually responded to Meads by denouncing that decision on moral and political bases, or as obiter. ${ }^{243}$ The Study Group litigants are among the most persistent and skillful OPCA litigants. Their treatment of Meads is therefore a point of interest. Did this subpopulation have a more substantive or effective response than those described in reported trial decisions and academic analysis of OPCA litigation?

Twenty Study Group applications were filed after Meads was released, of which 16 involved OPCA concepts. Meads was referenced in half $(n=8)$ of the pre-Supreme Court of Canada trial and subordinate appellate proceedings:

- $\quad$ Cited in reported lower court decisions: Dalle Rive 35874, Bossé 36026, Royer 37408, Dove 37487, d'Abadie 37507/8.

- Leave applications indicate Meads was referenced as an unfavourable authority: Dalle Rive 35874, Fong 36509, Barens 37656.

The frequent reliance on Meads in reported post-2012 lower court decisions associated with Study Group OPCA applications is unsurprising. This simply reflects Canadian courts' broad application of Meads as an authority in response to OPCA motifs. ${ }^{244}$

Interestingly, post-2012 Study Group applications generally ignored Meads and other antiOPCA jurisprudence. Only three leave applications mentioned Meads at all.

Fong 36509 implies Meads has a restricted potential relevance, as the underlying action was "a matrimonial matter, was simply the appointment of a case management justice; nothing more." ${ }^{245}$ This decision was inappropriate as Associate Chief Justice Rooke was (allegedly) "acting as an undeclared legal counsel," "going on a rampage," and "an abuse of the principle of Stari Decisis." 246

Cardinal v Cleveland Indians Baseball Company Limited Partnership, 2016 ONSC 6929; Jeff Gray, "Ontario Court Denies Bid to Block Cleveland Indians Name, Logo," The Globe and Mail (17 October 2016), online: <theglobeandmail.com/sports/baseball/use-of-cleveland-indians-name-and-logo-challen ged-in-ontario-court/article32392221/>.

Netolitzky, "Hammer," supra note 21 at 1186-92.

Ibid at 1196-97.

Ibid at $1186-87$.

Fong 36509 at Part III, para 33.

Ibid at Part III, paras 33-34 [emphasis in original]. 
Similarly, Barens 37656 implies Meads was wrongly decided in relation to the status of international treaties. This appellant also complains he "was labeled delusional and mentally incompetent" in lower court decisions, which put him at risk of arrest and being "force medicated." 247 Dalle Rive 35874 simply claims Meads was "unrelated."248

Thus, the Study Group applications are consistent with the broader OPCA community pattern of ineffectual response to anti-pseudolaw jurisprudence. That is no surprise, given the gulf that separates Canadian law and the Pseudolaw Memeplex.

This investigation located no evidence that the reasoning and conclusions in Meads and its successor decisions are not implicitly accepted by the Supreme Court as correct. The high DS of the Study Group applications provides substantial confidence in the merit of this broadly applied trial court decision.

\section{SELF-REPRESENTEd LitigantS AT THE SUPREME COURT OF CANADA}

This review permits a preliminary investigation of certain aspects of how the Supreme Court of Canada responds to SRLs, albeit an unusual subtype of that larger population.

First, there is no indication that the kisikawpimootewin Effect meant a potentially valid leave application was misidentified as unmeritorious due to its OPCA content and context. However, this observation proves little about the Supreme Court of Canada's ability to interpret OPCA leave applications, since the Study Group applications that involved OPCA concepts and language did not include any obviously valid basis for the Supreme Court to intervene.

A second question is bias. An introductory "Note" in Lindsay 34331 expresses concern about judicial bias against SRLs at the Supreme Court. ${ }^{249}$ This followed from Lindsay reportedly attending a public speaking engagement in Kelowna by then Chief Justice McLachlin. Lindsay says he asked Chief Justice McLachlin about the issue of SRL appeals, and noted at least two of his five appeals "easily met the test for Leave to be granted." Chief Justice McLachlin responded: "Keep on trying."

Lindsay 34331 follows with 2000-2007 statistics that indicate that in total 914 SRL applications were filed, 841 were evaluated on their merits, but only three SRL applications were granted leave. Lindsay does not identify the source of this data, but his values appear consistent with official Supreme Court of Canada reports. ${ }^{250}$

Whether the Study Group applications substantiate Lindsay's allegation of possible issues with Supreme Court review of SRL applications is an interesting and important question.

Barens 37656 at $4-5$.

Dalle Rive 35874 at para 12.

Lindsay 34331 at 1.

R Nicholson, Supreme Court of Canada Performance Report For the Period Ending March 31, 2008 at 17, online: Treasury Board of Canada Secretariat <tbs-sct.gc.ca/dpr-rmr/2007-2008/inst/jsc/jsceng.pdf $>$. 
Lindsay's concerns are certainly not unique. Public and academic commentary has challenged whether SRLs and represented litigants operate on a level playing field. ${ }^{251}$ In Pintea v. Johns, ${ }^{252}$ the Supreme Court identified SRLs as a special litigant category who require different treatment given their restricted knowledge of law and court procedures. SRLs are vulnerable people, given law's complex and alien character.

However, OPCA concepts are generally accepted as abusive, and litigants with that belief system are broadly denounced. ${ }^{253}$

The SRL OPCA Study Group leave applications were obviously either hopeless or incomprehensible, and therefore provide little assistance to evaluate this question. Several of the "conventional" non-OPCA appeals are more helpful. Unsurprisingly, Lindsay is the appellant or implicated in each.

Lindsay 26150, Lindsay 27181, and Lindsay 31204 ask whether state funded court transcripts should be provided in certain circumstances. As Lindsay correctly observes, transcripts are often a mandatory requirement for an appeal. Transcript preparation can involve significant expense. To date, appeal courts have rejected state-funded transcripts as an absolute right, ${ }^{254}$ and Lindsay's Magna Carta-based argument was specifically dismissed by the Supreme Court of Canada in Collinge v. Gee. ${ }^{255}$ Nevertheless, the past and present approaches to funding transcripts has been the subject of academic criticism for imposing an allegedly unfair expense on SRLs, and, as a result, impeding access to justice. ${ }^{256}$

The decades since Lindsay's original complaints on this issue have seen substantial evolution in the law concerning SRLs. Lindsay's three transcript-related appeals predate Trial Lawyers Association of British Columbia v. British Columbia (Attorney General), ${ }^{257}$ which required court filing fee waivers where court fees cause economic hardship. Plausibly, transcript costs are now an issue that merits Supreme Court commentary, if nothing else to establish whether certain economic circumstances may warrant a transcript being ordered by a court, or paid for by legal aid or an opposing party.

Similarly, in the Dick 29128 leave application, Lindsay argued the increasing number of SRLs in Canadian courts and the high price of legal service combined to make non-lawyer representatives a practical and functional necessity. This, too, is a concern that resonates in the modern Canadian SRL context. ${ }^{258}$ In these senses, Lindsay was arguably an "early

See e.g. Julie Macfarlane, "The National Self-Represented Litigants Project: Identifying and Meeting the Needs of Self-Represented Litigants" (May 2013), online: <representingyourselfcanada.com/wpcontent/uploads/2015/07/nsrlp-srl-research-study-final-report.pdf`. 2017 SCC 23 [Pintea].

Unrau, supra note 23 at para 180.

See Pavlis v HSBC Bank Canada, 2009 BCCA 450; $R$ v L'Espinay, 2008 BCCA 20; Versluce Estate $v$ Knol, 2008 YKCA 3, leave to appeal to SCC refused, 32584 (24 July 2008); Ocean v Economical Mutual Insurance Company, 2011 NSCA 106; Taylor v St Denis, 2015 SKCA 1.

$255 \quad$ [1968] SCR 948

256 Kaila Scarrow, Becky Robinet \& Julie Macfarlane, "Is Access to Court Transcripts in Canada an A2J Issue?" (National Self-Represented Litigants Project, June 2018), online: $<$ representingyourselfcanada. com/wp-content/uploads/2018/06/Transcript-Report-Final.pdf $>$.

$257 \quad 2014$ SCC 59.

258 See e.g. Alice Woolley \& Trevor Farrow, "Addressing Access to Justice Through New Legal Service Providers: Opportunities and Challenges" (2016) 3:3 Texas A\&M L Rev 549. 
pioneer" of the current influx of SRLs in Canadian courts. A Supreme Court appeal hearing that involves this unusually experienced SRL, presenting SRL perspectives, would be a fascinating exercise.

A third question is how well is the Supreme Court informed about OPCA concepts and court-related conduct? Plausibly, trial rather than appeal courts are the expert bodies for this subject. ${ }^{259}$ Since the Supreme Court has not issued any judgments on this topic, the case summaries prepared by Supreme Court court counsel are the only tool to evaluate this question.

Surprisingly, these summaries often do not document OPCA appeal issues raised in the leave applications. For example, the summaries for Fong 26509, Thompson 36111, Royer 37408, and d'Abadie 37507 do not reflect the "Strawman" duality arguments that made up much of the leave applications. This omission is difficult to understand, considering that several corresponding lower court decisions cited court authorities that describe and reject "Strawman" arguments. In contrast, the Bossé 36026 case summary more accurately reflects the Bossés' A4V “money for nothing” OPCA argument than the leave application written by Fuhgeh.

In other instances, the leave summaries simply restate what occurred in earlier proceedings and omit the pseudolegal appeal components. Admittedly, that approach is probably the best possible response to borderline incoherent applications, such as Fallis 31004, Williams 33209, Williams 33211, Henry 34172, and AC 37380.

Probably little should be read into these case summaries, since the summaries may not reflect the leave application review process as a whole. Nevertheless, the observed failure to accurately describe "Strawman" duality arguments in the post-Meads era is surprising.

\section{Should The Supreme COURT of Canada Grant Leave?}

To date no OPCA-based appeal has been granted leave by the Supreme Court. That outcome is no surprise. These ideas are pseudolaw, and devoid of merit. Why would the Court waste its restricted resources on spurious, ahistorical fabrications?

The most plausible scenario where pseudolaw might receive a substantive review is if an OPCA accused obtained a split decision from a court of appeal and then appeal by right to the Supreme Court became available. Given the universal rejection of pseudolaw by Canadian courts, the dissenting Court of Appeal opinion would almost certainly relate to a non-OPCA issue. Nevertheless, an OPCA litigant who has the opportunity to make submissions to the Supreme Court could and likely would advance pseudolaw at the appeal proceeding. 
Should the Supreme Court ever consider a purely OPCA-based appeal, despite its lack of legal merit? Arguably, there is a reason to doing so. The recent Hryniak v. Mauldin, ${ }^{260} R . v$. Jordan, ${ }^{261}$ and R. v. Cody ${ }^{262}$ decisions have directed a fundamental re-orientation in Canadian litigation from a strictly formal to more functional and resource-efficient approach. In Pintea v. Johns, the Supreme Court indicated SRLs require different treatment because of their unrepresented status. ${ }^{263}$

Because pseudolaw has no actual validity, OPCA litigants by definition abuse court processes when they advance these ideas. Furthermore, Canadian case law on this subject is now highly developed. ${ }^{264}$ Post-Meads, an OPCA litigant is unlikely to enter court, let alone an appeal court, unaware that the ideas he or she intends to argue have been the target of strong court criticism.

Nevertheless, some OPCA litigants' belief in pseudolaw is apparently sincere. That conclusion is obvious from the Study Group leave applications themselves. Most applications were carefully drafted, substantive attempts to argue pseudolaw issues. Many Study Group SRL leave applications were comparable or superior to those prepared by Study Group lawyers. Social scientists who have investigated these populations confirm there are true believers in this community who are driven by a combination of conspiratorial and political beliefs, reinforced in a kind of social echo chamber. ${ }^{265}$

When viewed exclusively from a government and court perspective, pseudolaw is nothing but a waste of state and institutional resources. That perspective misses something important. Pseudolaw leads to self-inflicted injury by those who advance these toxic ideas, including increased litigation damages and costs, criminal sanctions, psychiatric detention, foreclosed homes, and broken families. ${ }^{266}$ In a very real sense, OPCA litigants are the victims of the conman gurus who sell supposed secrets to the real but concealed law. ${ }^{267}$ Worse, OPCA theories authorize unorthodox and illegal actions against government, police, and court workers, including violence. ${ }^{268}$

Pseudolaw is a form of legal quackery or snake oil. Much as doctors and scientists are the most effective critics of pseudomedical and pseudoscience frauds, courts are the expert bodies logically and functionally positioned to refute OPCA misconceptions with clear, substantive, and responsive court decisions. ${ }^{269}$

2014 SCC 7.

2016 SCC 27.

2017 SCC 31.

Pintea, supra note 252.

Some OPCA concepts are so notoriously bad that courts have concluded that any attempts to advance these arguments creates a reverse onus on the OPCA litigant to establish their litigation has merit: Fiander, supra note 17; Rothweiler \#3, supra note 44.

265 Perry, Hofmann \& Scrivens, supra note 18 at paras 35-37; Jennifer Pytyck \& Gary A Chaimowitz, "The Sovereign Citizen Movement and Fitness to Stand Trial" (2013) 12:2 Intl J Forensic Mental Health 149. Netolitzky, "History," supra note 18 at 635-36, calls this paranoid and introspective social space the "OPCAsphere."

266 Netolitzky, "History," ibid at 641-42.

Courts have said as much, for example: Robert John: of the familymacmillan $v$ Johannson, 2017 BCSC 1069 at para 10; Servus, supra note 44 at paras 1-2, 83-84; Pomerleau, supra note 12 at paras 158-60; Canadian Imperial Bank of Commerce v McDougald, 2017 ABQB 124 at paras 63-65. 
In Canada, that has occurred, and Canadian court decisions, including Meads, are cited in other jurisdictions for that reason. ${ }^{270}$ Nevertheless, a clear and explicit rejection by the Supreme Court of Canada of core OPCA concepts would send a powerful message. As previously discussed, OPCA litigants are intensely interested in and believe in the rule of law. They read and study court judgments, and acknowledge the critical social function of courts. The OPCA community would therefore be very hard pressed to ignore a detailed and forceful rebuttal of key pseudolaw concepts, such as the "Strawman" duality, by this nation's highest court.

If the Supreme Court of Canada were to directly respond to a pseudolaw-based appeal, then ideally that would be to a well-written and thoroughly argued appeal. The surprisingly high quality of some SRL OPCA leave applications identified in this study shows that precondition for a substantial Supreme Court response is far from implausible.

Regardless of how any OPCA issue might find its way to the Supreme Court of Canada for a full hearing, the Supreme Court should, if possible, provide a substantive answer to that pseudolaw. The Supreme Court requires lower courts meet that standard, ${ }^{271}$ and here there is a listening layperson audience. A decision in this subject domain would require the Supreme Court to delve in some unusual directions, but the result may provide a real benefit to a population of SRLs who are vulnerable as a consequence of their misguided social, political, and (pseudo)legal beliefs.

\section{CONCLusion}

Sometimes silence speaks volumes. This investigation illustrates that point. The Study Group leave applications include many pseudolaw-based inquiries that the Supreme Court of Canada saw no need to answer. That silence has meaning, given the high DS of these issues. Pseudolaw is not the law of Canada.

That outcome is not really a surprise. Although populations in a dozen (or more) countries have been exposed to and adopted the Pseudolaw Memeplex, no court has endorsed its matrix of interlinked concepts. ${ }^{272}$ In that sense, this study is probably not of much direct assistance to trial courts.

This article's chief utility is instead as a direct challenge to OPCA litigants. Your ideas are so bad that the Supreme Court of Canada has repeatedly refused to even consider them. In particularly, the keystone "Strawman" Theory has been repeatedly ignored. As Master Schulz declared in Pomerleau v. Canada (Revenue Agency): "The 'Strawman' is a lie.."273

The Study Group leave applications also illustrate another important fact. Certain academic commentators have attempted to draw a bright line between "good SRLs" who are honest, fair-dealing court actors, and "bad SRLs," who are abusive, waste court resources,

Ibid at 664-65; Netolitzky, "Hammer," supra note 21 at 1186-89.

$R v$ Sheppard, 2002 SCC 26.

Netolitzky, "Pathogen," supra note 19.

Pomerleau, supra note 12 at heading V(B)(2). 
and are "vexatious." 274 These academics have expressed concern that judges will "conflate" the "good SRLs" with the "bad OPCA SRLs," which is an "ethical" issue.

The truth is less convenient. Many Study Group appellants defy this dichotomy. ${ }^{275}$ Their applications illustrate a genuine attempt to understand law and argue their concepts. Others straddle the line, advancing both reasonable appeal issues, but also ridiculous pseudolaw. Then there is David Kevin Lindsay, who has for decades been an extremely active court litigant and representative. Judges have frequently denounced Lindsay, and with good reason. ${ }^{276} \mathrm{He}$ has been repeatedly designated as a vexatious litigant, and rejected as an appropriate litigation representative.

However, Lindsay's personal and proxy Study Group applications identify and argue potentially meritorious legal issues in a largely competent and respectful manner. Lindsay is not just an abusive OPCA court participant. He is other things too, and, in many senses, was a litigant ahead of his time. Lindsay in the 1990s and early 2000s argued some issues now identified as important for SRLs.

The Study Group applications show that some in the OPCA population are organized, careful, but highly unorthodox and indoctrinated thinkers. This more thoughtful segment of the OPCA communities appears to be overrepresented in the Study Group population. These people are without question committed to the Pseudolaw Memeplex. Their capacity to express pseudolaw concepts is linked, at least in part, to their host movements. Freeman applications were markedly inferior to those of the anti-tax Pre-Detaxer and Detaxer communities.

Though perhaps at first incongruous, this study demonstrates a real confidence by OPCA affiliates in the court apparatus and judiciary. The Study Group OPCA applicants took their concepts to the high court of the country, where they made substantial efforts to argue the (pseudo)law they believe is true. They only rarely resorted to unorthodox means, such as magic and ceremony, or vigilante authorities. These facts suggest these legal dissidents not only believe in their ideas, but that they would receive a fair hearing of the matters they bring to court.

To be fair, an alternative explanation is that the kinds of radical change of state function and law sought by many OPCA litigants are unlikely to occur by political organization and activity, and certainly not by armed revolution. In many ways, Canadian courts may be a

Julie Macfarlane, "Avoiding Conflation: OPCAs and Self Represented Litigants" (6 October 2012) online (blog): NSRLP<representingyourselfcanada.com/avoiding-conflation-opcas-and-self-representedlitigants/>. See also Julie Macfarlane, "The 'Scourge' of Self-Representation?" (12 January 2013), online (blog): NSRLP <representingyourselfcanada.com/the-scourge-of-self-representation/>; Alice Woolley, "The Top Ten Canadian Legal Ethics Stories - 2012" (3 January 2013), online (blog): <ablawg.ca/2013/01/03/the-top-ten-canadian-legal-ethics-stories-2012/>; Amy Salyzyn, "Canada: Foreclosures, Freemen, Foreign Law Schools and the Continuing Search for Meaningful Access to Justice" (2013) 16:1 Leg Ethics 223; Jonnette Watson Hamilton, "The Increasing Risk of Conflating Self-Represented and Vexatious Litigants" (17 September 2018), online (blog): <ablawg.ca/2018/ 09/17/the-increasing-risk-of-conflating-self-represented-and-vexatious-litigants/> . 
more plausible mechanism to achieve extraordinary results that cause a basic reorganization of Canadian society, rather than other forms of social activism and resistance.

Last, any extrapolation of this investigation's results to the Supreme Court of Canada SRL population in general should be done with caution. At this point, the larger set is little understood, so there may be substantial differences between these two partially overlapping populations. That said, future investigation of the total Supreme Court SRL litigation population would be very interesting. For example, are SRL appeals at the Supreme Court of Canada also usually substantive attempts to argue law? What issues bring SRLs to the Supreme Court? Are Supreme Court appeals of what lower courts call "vexatious litigation" predominately attempts to impose unorthodox law, or uncontrolled litigation, typically by persons with mental health issues? ${ }^{277}$ This successful investigation of the Study Group applications indicates a quantitative investigation of these broader questions is feasible. That may shed useful light on the SRL phenomenon as a whole. 
[this page is intentionally blank] 